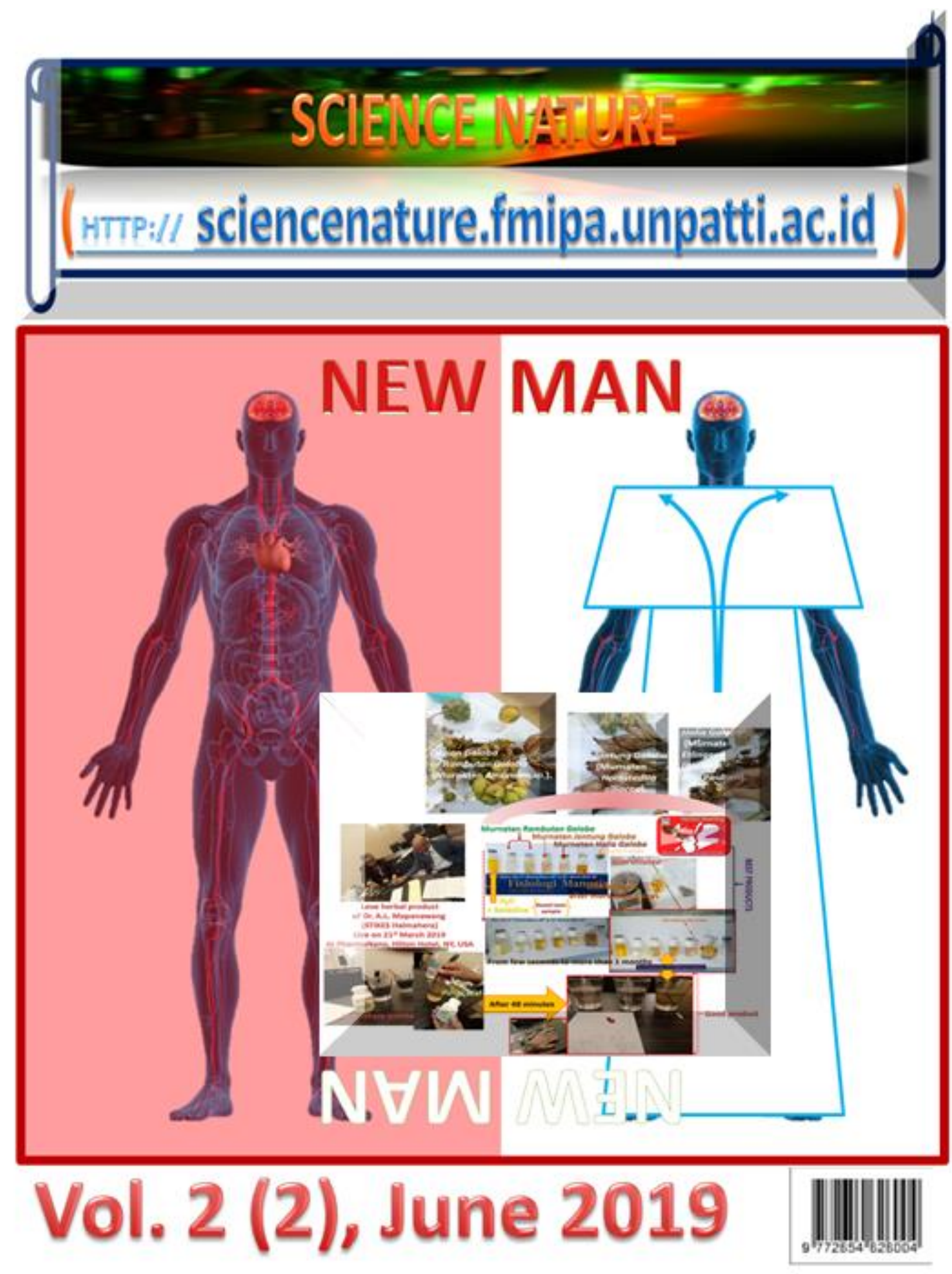




\section{Editor in Chief: Assoc. Prof. Hendry Izaac Elim, Ph.D.}

(2017 Young Scientist Indonesia of Pattimura University)

URL: http://fisika.fmipa.unpatti.ac.id/hendry-izaac-elim

\section{Assitant Editors:}

[1]. Asst.Prof. Yopi Andry Lesnussa, S.Si., M.Si. (Mathematics Department, Pattimura University)

[2]. Dr. I Wayan Sutapa, S.Si., M.Si. (Chemistry Department, Pattimura University)

[3]. Dr. A. Pesik, SP, M.Si. (Biology Department, Pattimura University

[4]. Dr. H.J. Wattimanela, S.Si., M,Si. (Statistical Department, Pattimura University)

\section{Editorial Board Team (5 Continents Representative):}

[1]. Dr. K. Ishikawa

(Senior Scientist at AIST), Japan, Asia Continent

[2]. Prof. C. Baskar, Ph.D

(Teerthanker Mahaveer Univ.), India, Asia Continent

[3]. Prof. Naoyasu Kita

(Kumamoto University), Japan, Asia Continent

[4]. Prof. Nail Akhmediev

(Nonlinear Optics Expert, ANU, Canbera), Australia, Australia Continent

[5]. Prof. Dieter D. Genske

(Geo-technique Expert, Nordhausen Univ. of Applied sciences), Germany, European Continent

[6]. Prof. Dr.-Ing. Joachim Fischer

(Renewable Energy), Germany, European Continent

[7]. Prof. Xudong Huang, Ph.D

(Harvard Medical School \& Massachusetts General Hospital | MGH ), USA, American Continent

[8]. Prof. Long Y. Chiang. Ph.D

(Chemistry Professor, University of Massachusetts Lowell, USA, American Continent)

[9]. Dr. M.V. Reddy

(Senior Scientist at Hydro-Quebec, Canada), North America, American continent

[10]. Prof. Dr. Fabian Ezema

(Univ. of Nigeria, Nsukka), Nigeria, African Continent

[11]. Dr. Bonex Mwakikunga

(CSIR, Africa), South Africa, African Continent

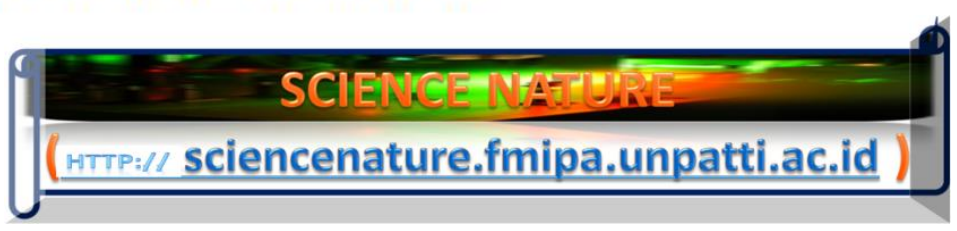

\section{Publisher:}

Faculty of Mathematics and Natural Sciences

Pattimura University

Address: Jln. Ir. Martinus Putuhena, Poka - Ambon, Indonesia 97233

e-mail: editor.sciencenature@fmipa.unpatti.ac.id | Mobile Phone: (+62) 85243836774 (Dr. Elim)

http://sciencenature.fmipa.unpatti.ac.id/index.php/archieve/; or

https://ojs3.unpatti.ac.id/index.php/sciencenature/

Copyright @ FMIPA UNPATTI 2019

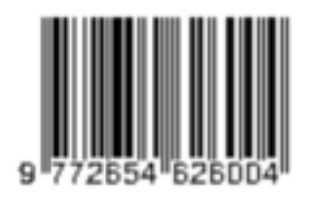




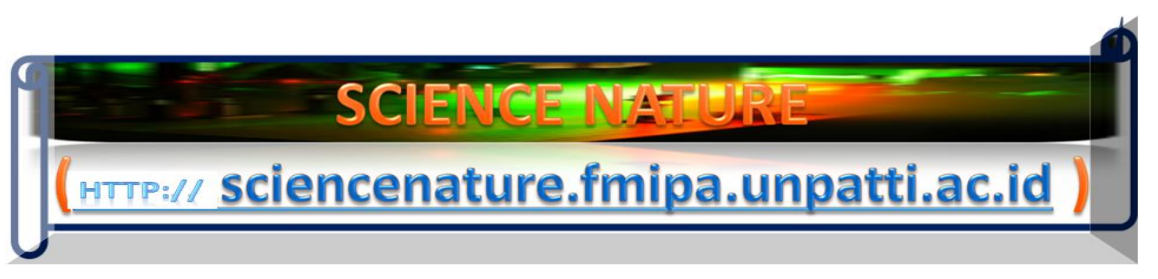

\section{LIST OF CONTENTS}

INTERPRETATION OF ALTERATION

MINERALS AROUND THE OMA-HARUKU

HOT SPRINGS, CENTRAL OF MOLUCCAS

DOI: https://doi.org/10.30598/SNVol21ss1pp090-096year2019

Pangi Leaf (Pangium edule Reinw) Herbal

Medicine: A Marvelous Candidate for the

Prominent HIV Herbal Medicine

DOI: https://doi.org/10.30598/SNVol2Iss1pp097-104year2019
Helda Andayany*

Josephus Ronny Kelibulin

$090-096$

Arend L. Mapawawang

Hendry Izaac Elim*

$097-104$
$105-113$

Martinus J. Saptenno*

Sostones Sisinaru

Edwin Ubwarin

William A. Siahaya

H. I. Elim $\#$

Products in Aru Islands Region of Maluku Province, Indonesia

DOI: https://doi.org/10.30598/SNVol2Iss1pp105-113year2019

\section{A Frontier 2D Nanobattery: "Improving} Challenges (Hotumese) and Development" DOI: https://doi.org/10.30598/SNVol2Iss1pp114-121 year2019

The Observation of Fast, Long Term, and Stable Performance of Toxic Absorption in

Ido F. Seay

Hendry I. Elim*

$114-121$

M.V. Reddy

Rajan Jose

Herbal Blessing Product Based on Galoba

Maluku (Zingiberaceae Fruits)

DOI: $\underline{\text { https://doi.org/10.30598/SNVol2Iss1pp122-127year2019 }}$ 


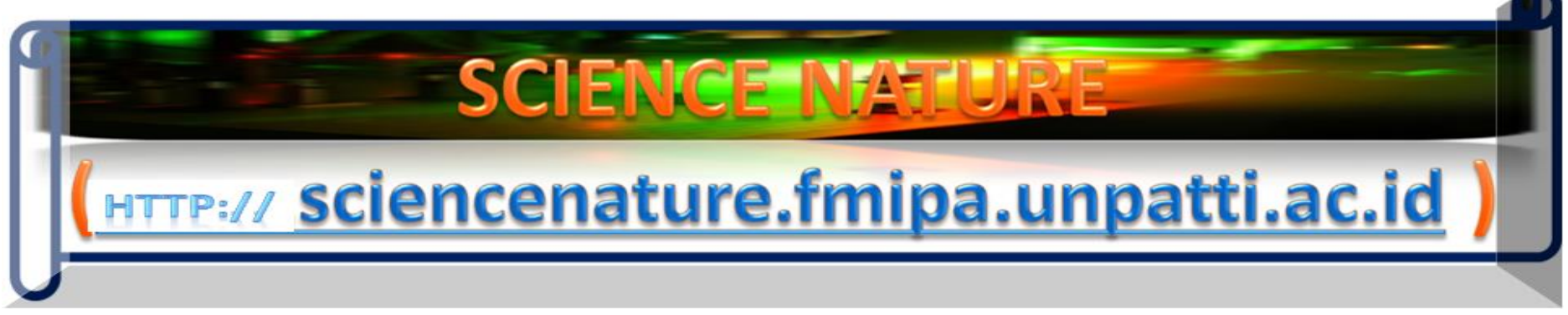

The scientific scope of this newly frontier multidisciplinary journal involve the following three main points:

(i). Educating scientists for their better contribution for others,

(ii). Developing knowledge and improving wisdom of people based on excellent understanding of the truth in nature and science

(iii). Engineering scientific findings of real technology, and its useful products such as medicine products, foods, and drinks output, and another useable human daily products and smart devices as well as applied engineering technology products involving mass transportation vehicles, and movable building system.

While the fields contributed to make such significant points based on novel scientific contributions are from multidisciplinary science and technology as well as its integration in the philosophy of social sciences, arts and cultures.

Published by:

Faculty of Mathematics and Natural Sciences

Pattimura University

Address: JIn. Ir. Martinus Putuhena, Poka - Ambon, Maluku, Indonesia 97233

Email: editor.sciencenature@fmipa.unpatti.ac.id

Copyright $\odot$ FMIPA UNPATTI 2019 
Editor in Chief:

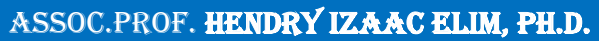

(PHYSICS DEPARTMENT, PATTIMUR UNIVERSTYY)

4 Assitant Editors:

\begin{tabular}{|c|c|}
\hline $\begin{array}{c}\text { Asst.Prof. Y.A. Lesnussa } \\
\text { (Mathematics Department, } \\
\text { Pattimura University) }\end{array}$ & $\begin{array}{c}\text { Dr. I Wayan Sutapa, S.Si., M.Si. } \\
\text { (Chemistry Department, } \\
\text { Pattimura University) }\end{array}$ \\
\hline $\begin{array}{c}\text { Dr. HJ. Wattimanela, M.Si } \\
\text { (Statistical Department, } \\
\text { Pattimura University) }\end{array}$ & $\begin{array}{c}\text { Dr. A. Pesik, S.Si, M.Si } \\
\text { (Biology Department, }\end{array}$ \\
\hline
\end{tabular}

11 Editorial Board (5 Continents Representative):

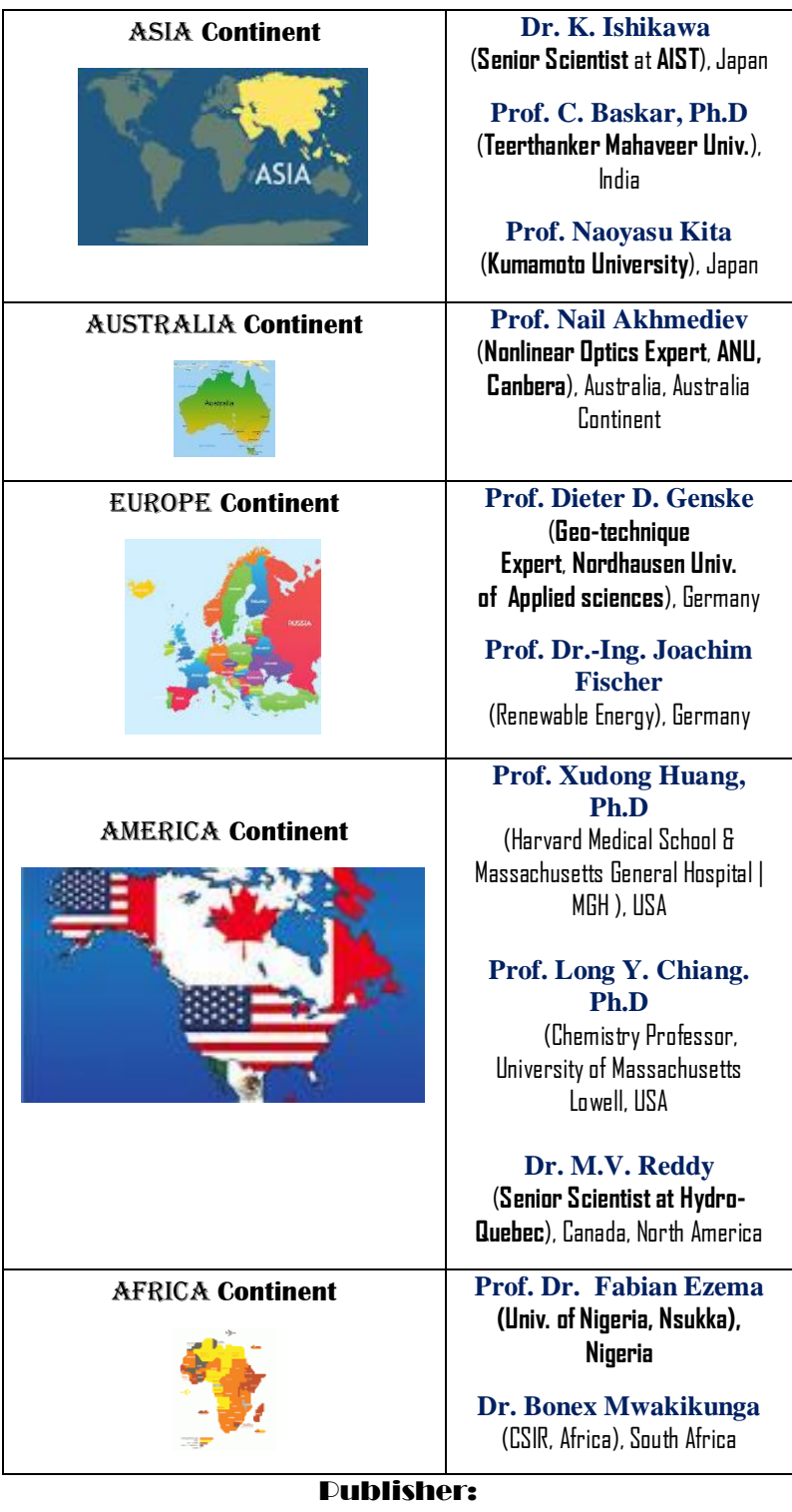

Faculty of Mathematics and Natural Sciences Dattimura University

Address: JIn. Ir. M. Putuhena, Poka - Ambon, 97233 e-mail: editor.sciencenature@fmipa.unpatti.ac.id Mobile Phone: (+62) 85243836774 (Dr. Elim) http://sciencenature.fmipa.unpatti.ac.id/index.php/archieve/; or https://ojs3.unpatti.ac.id/index.php/sciencenature/
How to Prepare your Research Results \& Its Quality to be published in SCIENCE NATURE

\section{A Brief GUIDELINE}

\section{[l]. Please check your Vision \& Mission of Publication as follow:}

The scientific scope of this newly frontier multidisciplinary journal involve the following three main points:

(i). Educating scientists for their better contribution for others,

(ii). Developing knowledge and improving wisdom of people based on excellent understanding of the truth in nature and science

(iii). Engineering scientific findings of real technology, and its useful products such as medicine products, foods, and drinks output, and another useable human daily products and smart devices as well as applied engineering technology products involving mass transportation vehicles, and movable building system.

While the fields contributed to make such significant points based on novel scientific contributions are from multidisciplinary science and technology as well as its integration in the philosophy of social sciences, arts and cultures.

\section{[ii]. Please Upload Science Nature TEMDLATE at her URL in the following link: http://sciencenature.fmipa.unpatti.ac.id and then prepare your manuscript for submission.}
[iii]. Make sure that your ENGLISH IS GOOD ENOUGH for the scientific publication.

[iv]. Your submission cannot be submitted in any other journal before the decision is made from SCIENCENATURE

E-ISSN: 2654-6264

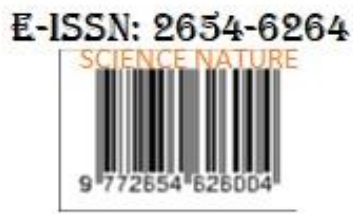




\section{SCIENCE NATURE DEVOTIONS}

\section{VOLUME 2, ISSUE 2 (2019)}

[XXXiV]. How EAR help your excellent learning (watch the videa). At least there are 3 steps of hearing process to improve your excellency from mechanical sound to electrical pulses to your sensitive and accurate brain millions of neurons.

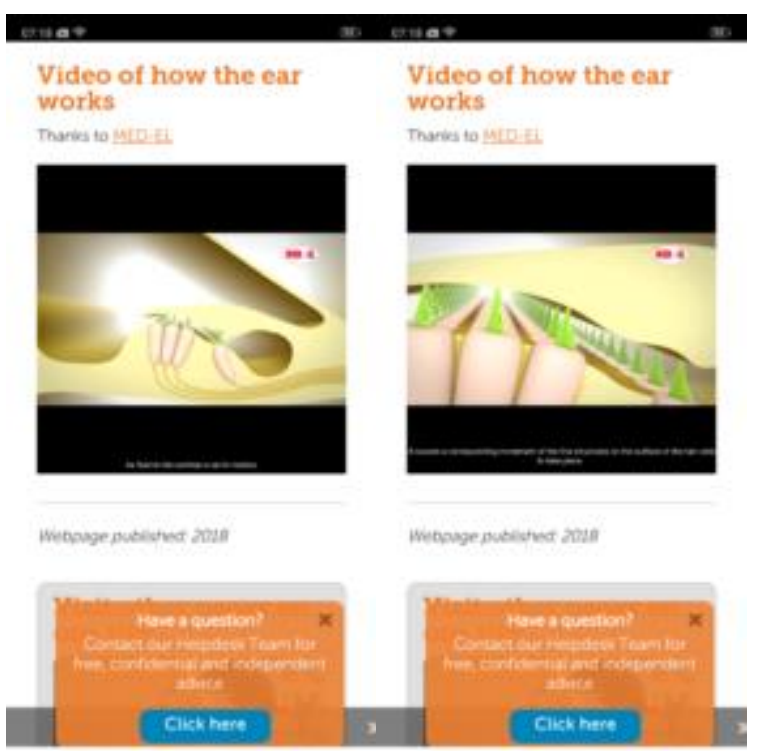

Spiritually, such message could be faund in Holy Bible, far instance in Zech. B:l5b.

[XxXiii]. The best scientific journals in rank QI are about 10\% based on SCDPUS data of 2018. While the largest number of citation in a single paper published in Applied Physics Letters (APL) of AlP was published in 1987 about organic electraluminescent diades with 11083 citations.
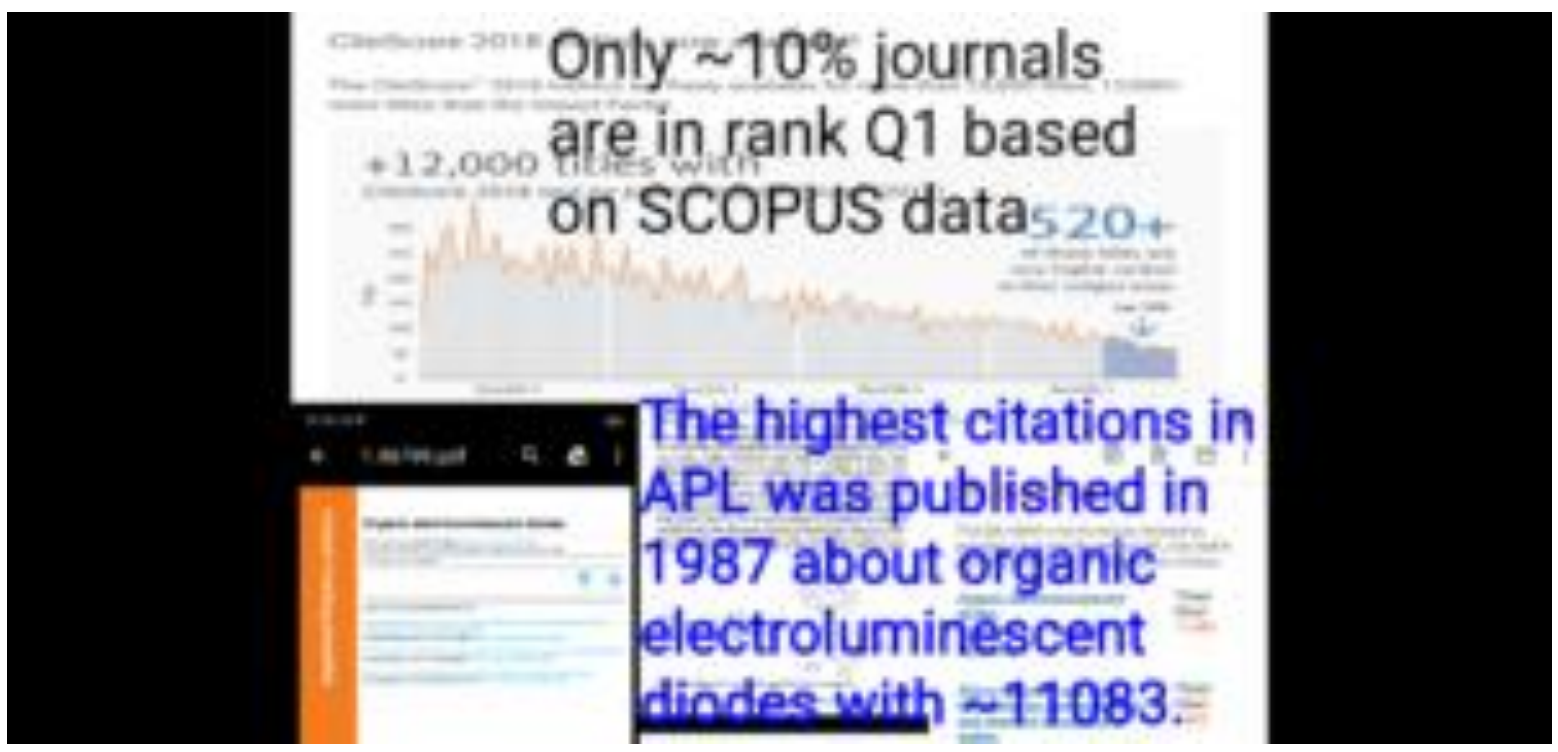
[XXXii]. The largest number of Science and Math competition among students in Maluku province was in 2019 with the total candidates of 1700.

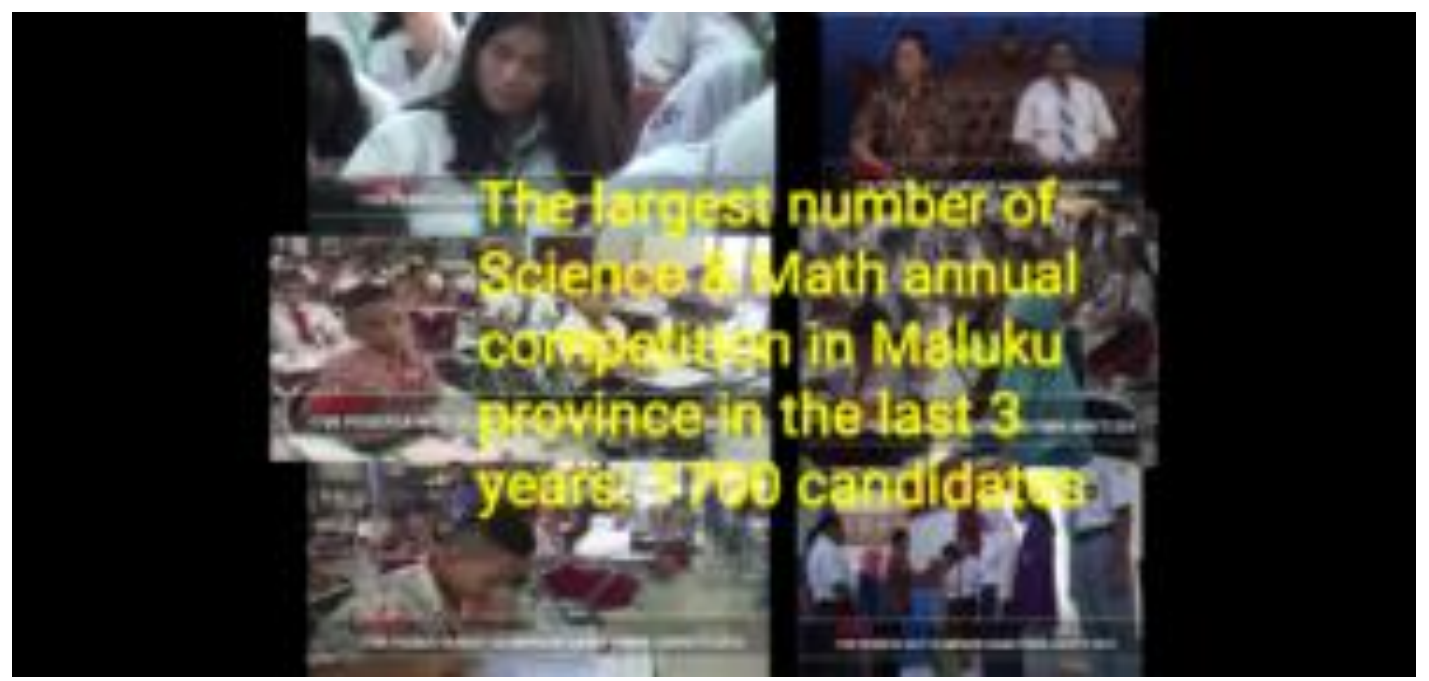

Such successful improvement of Faculty of Mathematics and Natural Sciences of Pattimura university in their excellent effarts during the last 3 years has shown a dramatically increase of parents-students cooperation in preparing their kids for a better future knowledge and understanding in science and technology.

[XXXi]. The 2nd best Certificate of Excellence given overseas from Science Nature was for Dr. M.V. Reddy, the Ist rank Asian scientist in the field of molten salt synthesis in his former research laboratory of nanobattery at National University of Singapore (NUS), Singapore on 13rd May 2019. The following news was prior to our Science Nature Devotions:

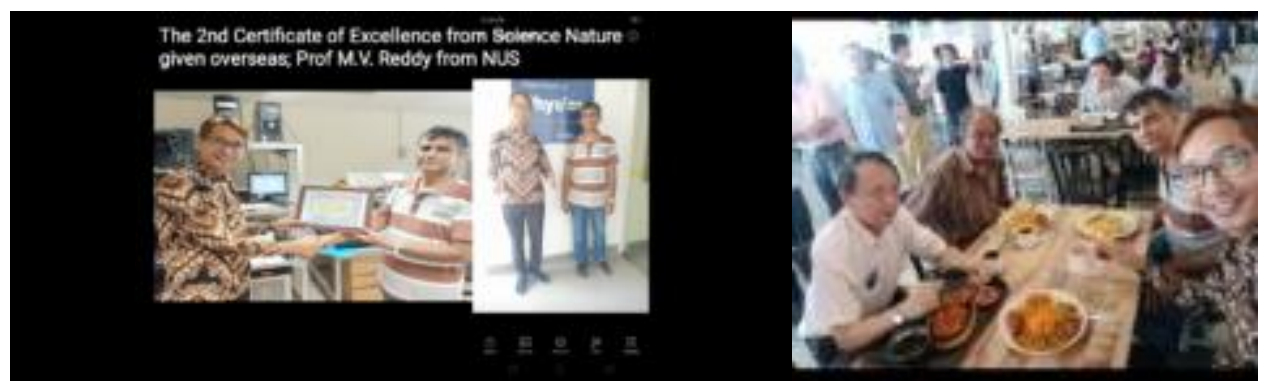


[XXX]. Holy life of college students are necessary. According to new report in Science on 24th May 2019 in it's Volume 364 an page 711, because of high rate practices as high as 60\% to 80\% of premarital sex and multiple sex partners among college students in China, the HIV infected college students are increased about 30\% to 50\% even though there were many effort have been carried out by China government.
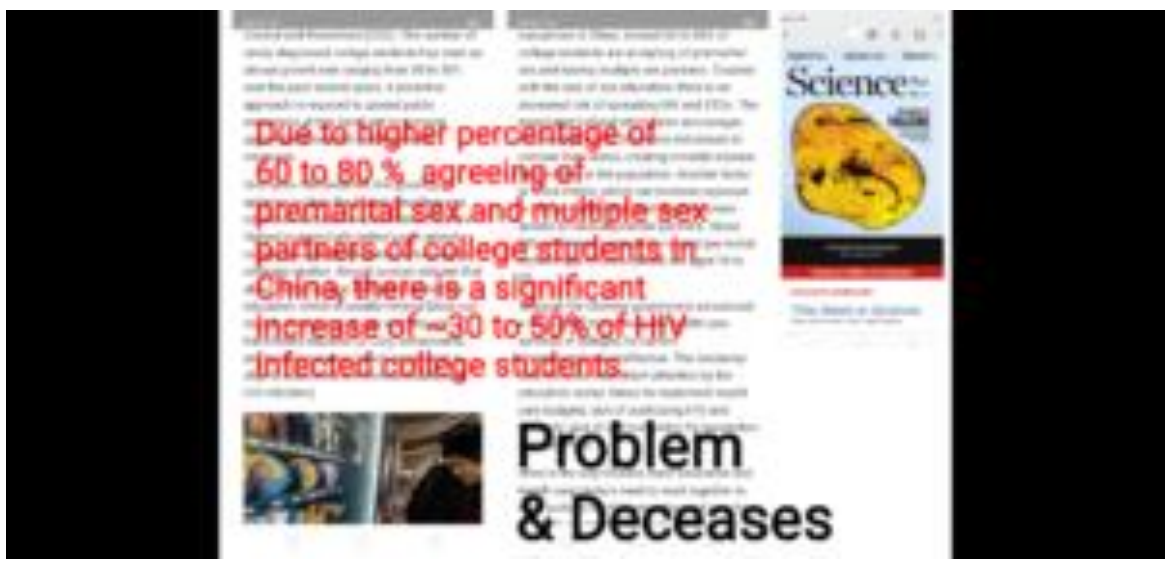
[XXiX]. Connecting your IDEA or NEVER: just like back in 2015 of "Publish or Perish" (19th May 2015, NATURE), and current of "Promate or Perish" (8th May 2019, AlP publishing) is a part of significant contribution to others. Recently, people need to value their idea to build anather people and it is a social media tool that can be able to connect these all people araund the world for a better knowl edge and understanding in a certain important time.

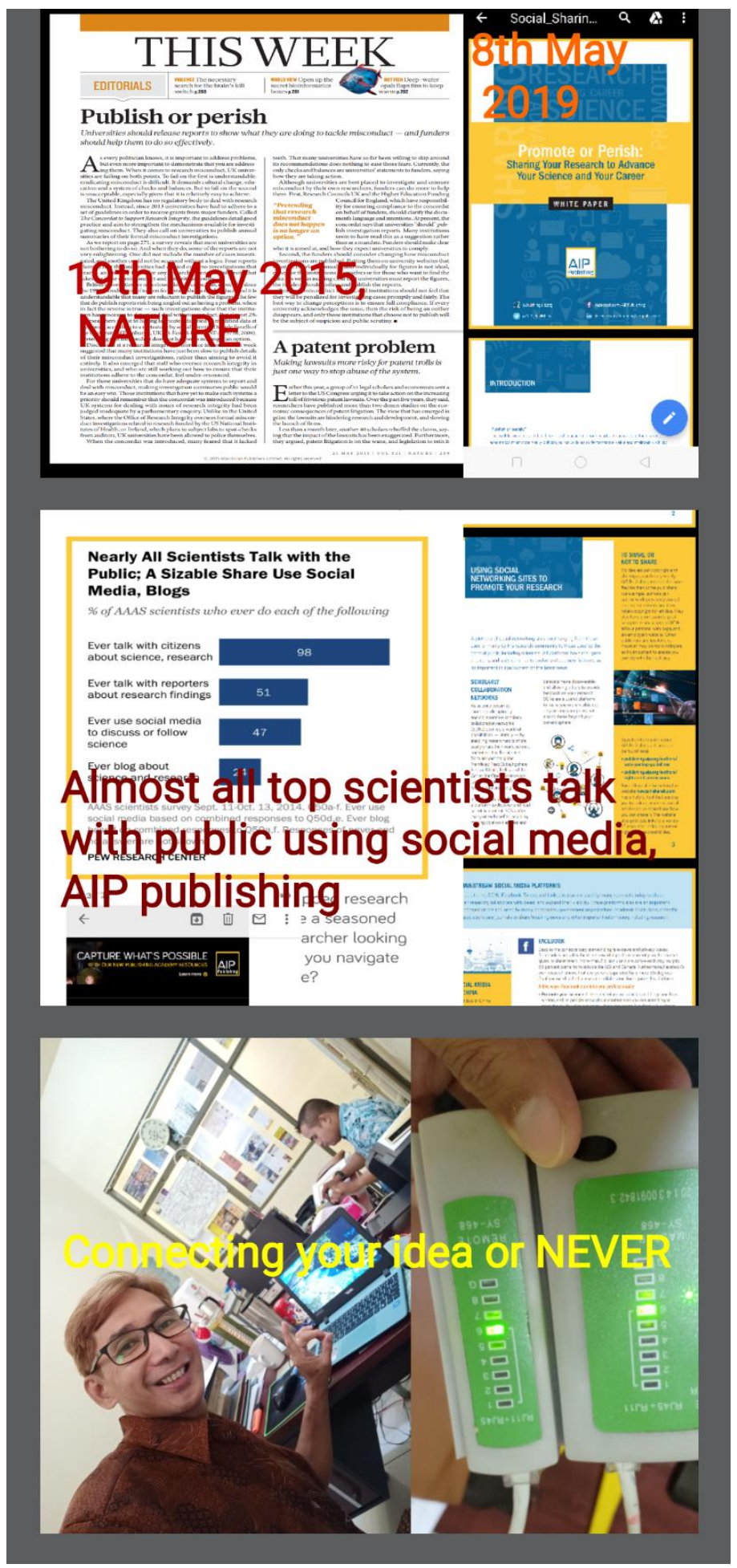

E-ISSN: 2654-6264 


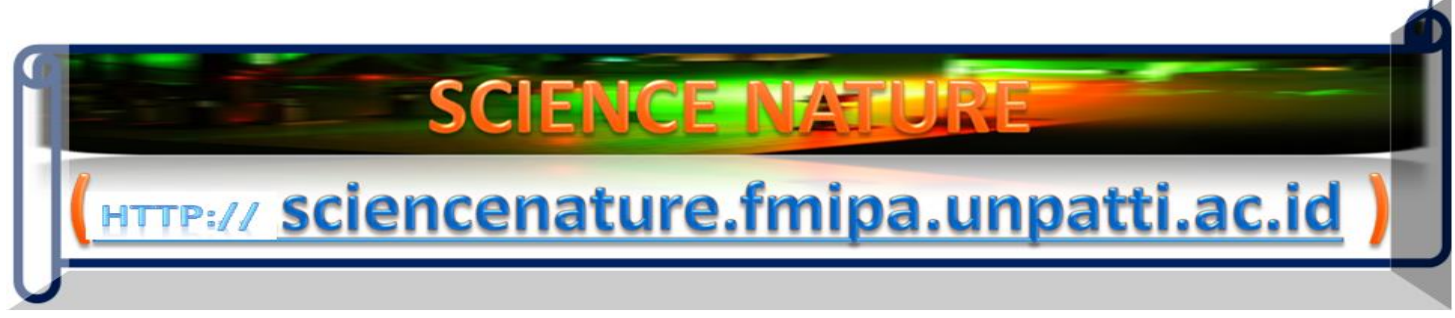

Science Nature 2(2), pp.090-096 (2019)

ISSN: 2654-6264

DOI: https://doi.org/10.30598/SNVol2Iss2pp090-096year2019

\title{
INTERPRETATION OF ALTERATION MINERALS AROUND THE OMA-HARUKU HOT SPRINGS, CENTRAL OF MOLUCCAS
}

\author{
Helda Andayany* , Josephus Ronny Kelibulin
}

Laboratory of Geophysics, Faculty of Mathematics And Natural Science, Pattimura University (UNPATTI), Jl. Ir. Martinus Putuhena, Kampus Poka, Ambon, Indonesia 97233

\begin{abstract}
Received : January 31, 2019
Revised : February 7, 2019

Published : May 20, 2019
\end{abstract}

Copyright @ All rights are reserved by Helda Andayany and Josephus Ronny Kelibulin

Corresponding author: "Email: heldaandayany2014@gmail.com 


\section{Abstract}

Petrographic analysis to rock samples located at Oma-Haruku hot springs was dominated by mudstone. Another alteration mineral types of the rocks in this area are quartz, aragonite/calcite and feldspar minerals. Petrographic analysis was supported by the XRD method. The method indicated that the alteration minerals content was generally dominated by the presence of aragonite/calcite with particle size of $0.05-2 \mathrm{~mm}$, the abundance of $55 \%$ and the spread evenly. Based on such presence of aragonite/calcite, one can interpret that the origin rock was carbonate. Alteration minerals which were generally dominated by mudstone indicate that the type of hot spring area in Oma-Haruku is a type of high-temperature reservoir, namely $>175{ }^{\circ} \mathrm{C}$. Therefore, the area is potentially as geothermal field in Central of Moluccas.

Keywords: $X R D$, petrography, carbonate, alteration minerals

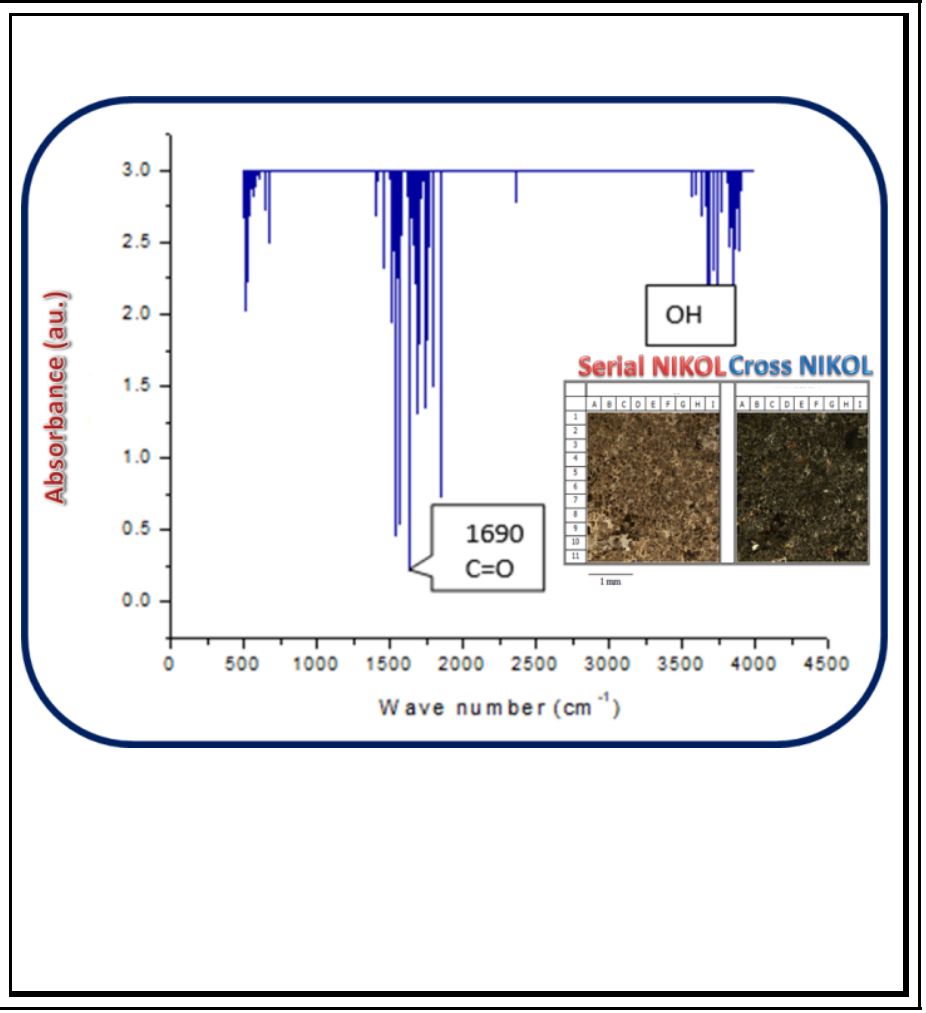

\section{ARTICLES}

\section{Introduction}

Fault structure of Oma-Haruku is a normal fault trending Southwestern - Northeast led to the emergence of manifestations hot springs with a surface temperature of the hot water is $58.8{ }^{\circ} \mathrm{C}$. Manifestation of hot springs in this area with regard to the presence of fractures in volcanic tuff unit is Middle Pliocene with composition of andesite lava. The exit of the hot springs of volcanic tuff fracture causes the volcanic tuff experienced changes both at the surface and at the fragment.

Physical circumstances around the Oma-Haruku hot springs brown materials are yellowish and there are also white on the surface with an indication of the surrounding alteration rocks. Depth research on the characteristics of mineral alteration by rock samples taken from the study in Oma-Haruku area hot springs performed using petrographic method.
Petrographic method was used to describe the texture of rocks to know the types of origin rock and alteration processes that occurs in rocks. Petrographic method was supported by XRD method with bulk analysis (analysis of powder and clay analysis). The XRD analysis results were a pattern that could explain the presence of alteration mineral deposits in the study area [1].

In addition, the rock samples also were analyzed using petrographic, so it can be spread and characterized the alteration of rocks on the surface of the hot springs Oma-Haruku. By mapping the alteration of rocks, it can be seen that the characteristics of geothermal fluid in the reservoir, and what happens when the fluid flow to the surface were observed.

The previous study to interpret the alteration minerals around the hot springs as mentioned in Ref. [2] that the petrographic analysis to rock samples located at Waiyari geothermal was dominated by feldspathic greywacke. On the other hand, the alteration mineral types of the rocks in this area are quartz, opaque, lithic, 
and feldspar minerals. The interpretation of alteration minerals show that the mineral types of the origin rock is sandstone tuff. Petrographic analysis is supported by the XRD method that indicated that the alteration minerals present are generally dominated by the presence of clays such as illite-chlorite with particle size $(<0.03 \mathrm{~mm})$, the abundance of $55 \%$ and the spread evenly [2].

To determine the pattern and characteristics of alteration of rocks, field description and sampling was conducted. Further alteration mineralogy rock constituent using petrographic analysis, the analysis of thin section which is supported by the analysis of X-ray diffraction (XRD).

Besides XRD, Specktroscopic FTIR (fourier transform infrared) is one of the good analytical technique in the process of identifying the molecular structure of a compound [3]. Figure 1 shows that there are $\mathrm{OH}$ groups with wave numbers ranging from 3600 to $3800 \mathrm{~cm}$ can have alcohol/fenol absorption. Beside that the area with the highest absorption than the sample is at the value with wave number $1690 \mathrm{~cm}^{-1} 1$ can have $\mathrm{C}=\mathrm{O}$ functional group. For absorption areas with wavelengths in this range have aragonite minerals with compounds are aldehydes with vibration stretching [4].

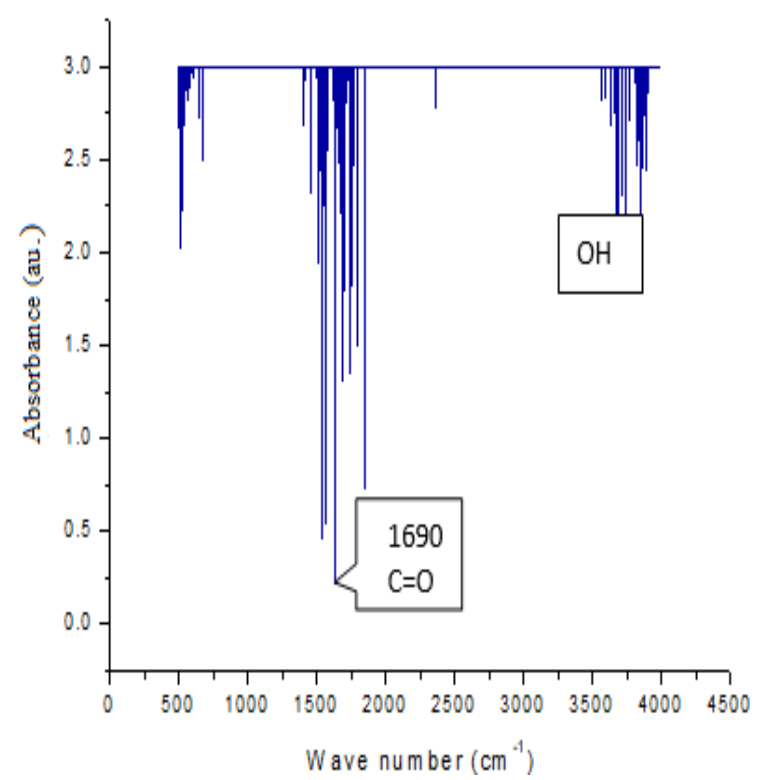

Figure 1. Graph of the absorbance spectrum of compound sample.
Their hot tubs in the wild are one indication of a geothermal resource below the surface. This hot water pool is formed by the flow of hot water from beneath the surface through fractures of the rock. The water source can be from the ground or from the water coming from the reservoir. When the water comes from the geothermal reservoir, the water is almost always neutral.

Ellis and Mahon in 1977 said that the element chloride insoluble in steam at temperatures below $300^{\circ} \mathrm{C}$. If the hot water sample analysis results obtained high chloride levels, it can be concluded type of geothermal reservoir is the kind of dominance hot water (water heated reservoir) [5].

Sulaiman, et. al. in 2007 stated that one of the geothermal prospects was the hot springs area of Akesahu with a $\mathrm{pH}$ between (7.4 to 7.9) which was largely of water with chloride type such as hot springs with Akesahu temperatures are relatively high, especially in Akesahu, Tomadou and Tanjungputus between (43.9 to 45.1$){ }^{\circ} \mathrm{C}$ and in the hot springs found their hot water deposits or sinter whitish, brown iron oxide. This indicates that the hot water system that appeared in Akesahu geothermal area lies in upflow zone and is a type of domination reservoir of hot water (water heated reservoir) [6].

In some manifestations of hot water in the study area of alteration of rocks are formed on the surface around the hot springs. Alteration of these rocks can indicate the characteristics of the geothermal water that never interacts with surrounding rocks. By combining active manifestation, namely hot water and other outputs, and the manifestation of the remainder, ie alteration of rocks, the history and evolution of a geothermal system can be known.

Mineral such as smectite clays, quartz, feldspar, chlorite, and illite can be use an indicator of the reservoir temperature. Smectice, has a temperature below (140-150) ${ }^{\circ} \mathrm{C}$. Based on result of research from several authors in the different fields obtained of temperature variation for these minerals. For example trioctahedal smectite (saponite) does not appear when the temperature reaches (85-95) ${ }^{\circ} \mathrm{C}$, then chlorite-smectite (corrensite) 
begin to form. Alteration minerals depends on several factors, but the main one is the temperature, pressure, type of origin rock, composition fluid (especially $\mathrm{pH}$ ) and duration of response. Alteration minerals produced in the surface zona typically is kaolin, alunite, sulfur, silica, residue and gypsum [7].

Evidence of geothermal activity is show by manifestations on the surface, indicating that hydrothermal fluid originating from the reservoir has come out through fractures or units of permeable rocks. Some manifestations are important to know because they can be used as indicators in determining the temperature of geothermal reservoirs, including: hot springs and silica sinter. Silica sinter derived from hydrothermal fluid enough to get a structure containing alkaline silica, precipitated when saturated fluid, amorphous silica cooled from $100^{\circ} \mathrm{C}$ to $50^{\circ} \mathrm{C}$. These deposits can be used as a good indicator for the presence of reservoir temperature $>175^{\circ} \mathrm{C}[8]$.

The appearance of silica sinter deposits on the surface is supported by water data which is the result of hot water activity where the value of silica sinter is relatively high. This usually indicates a high reservoir temperature. The rocks around these hot springs are converted into white alteration rocks and form brownish yellow deposits on the surface. In addition, hot water from the reservoir will reach the surface quickly and generally is a region with good permeability [9].

In addition, Hochstein \& Browne (2000) suggest that geothermal system activity is generally related to the formation of hydrothermal alteration minerals. Alteration minerals can be used as an indicator to find out an area that has geothermal potential. Hydrothermal alteration is a feature of texture changes, mineralogy and the chemical composition of a rock caused by hydrothermal fluid activity [10].

\section{EXPERIMENTAL METHOD}

The primary data in the study area, among others: the measurement of water temperature on the surface, hot water colors and color of alteration rock, and rock samples and sampling rocks at each measurement station.
Analysis of rock samples were calculated using the bulk XRD analysis (analysis of powder and clay analysis or analysis of clay). The results of the analysis form the XRD patterns will be processed so that the researchers could explain the presence of mineral deposits in the study area. Additionally, rock samples were also analyzed using petrographic methods. The results of the analysis will then be processed by the researchers to determine the value of the speed of mechanical waves propagating in the rock to determine the spread and characteristics of alteration of rocks around the hot springs and reservoirs of geothermal resources in the study area.

\section{RESULTS AND DISCUSSION}

Hot tubs Oma-Haruku located in the village of Haruku Island, Central Maluku regency. Geographically, the hot springs are located at coordinates between $3^{\circ} 34^{\prime} 11^{\prime \prime} \mathrm{S}$ and $128^{\circ} 29^{\prime} 16^{\prime \prime} \mathrm{E}$ with a height of $50 \mathrm{~m}$ above sea level. The measurement station has the average temperature is $58,8^{\circ} \mathrm{C}$ and the ambient temperature is $43,1^{\circ} \mathrm{C}$. Hot water Oma-Haruku accommodated in a pool of hot water dimension $2 \times 3 \mathrm{~m} 2$ with a depth of $0.5 \mathrm{~m}$ that flow into the rivers. Characteristics of the hot water is crystal clear, odorless sulfur, tasteless, and found a little precipitate iron oxide yellowish brown color on the surface. In addition, the hot springs Oma-Haruku found the hot water sediment or sinter whitish, brown iron oxide and the surrounding rocks already alteration. This usually indicates a high temperature reservoir.

The occurrence of boiling in the reservoir forms a fluid vapor gas temperature and relatively high pressure which exit through the cracks/fractures possibility of contamination of ground water. Pressure exerted by the fluid (hot water + steam) is greater than the outside air pressure and hydrothermal fluids below the surface of contaminated groundwater. The subsequent boiling in which fluid density decreases that made a break through to the surface (up flow) in the form of hot springs in several places in the Hot Springs area in Oma-Haruku. 


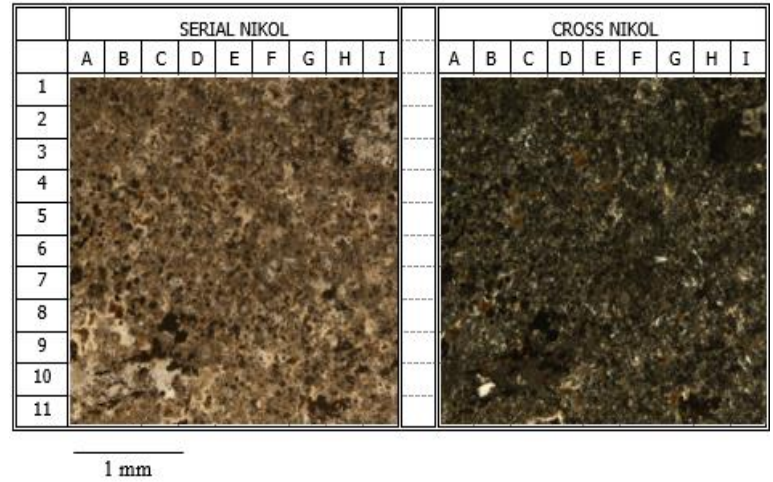

Figure 2. The incision rock samples in the Oma-Haruku hot springs area.

Characteristics of mineral alteration of rock samples taken from the study Oma-Haruku area hot springs performed using petrographic methods. Petrographic analysis results in Figure 2 show that the rock samples is dominated by mudstone, clastic texture showing incisions, closed containers, sorting good, from 0.05 to $2 \mathrm{~mm}$ grain size, grain shape sub-angular-rounded, composed of fragments and matrix, the abundance of 55 $\%$ in the rocks. Fragments in the form of quartz mineral, mineral aragonite/calcite and feldspar while the matrix in the form of clay minerals. Based on the presence of aragonite/calcite it can be interpreted that the origin rock is actually carbonate.

\section{CONCLUSION}

Hot water in Oma-Haruku thought to have come directly from a geothermal reservoir below the surface of the water with a neutral $\mathrm{pH}$. This shows the hot water in the village of Oma-Haruku island comes from the geothermal system dominance of water (water heated reservoir) by the flow of water to the upper reservoir (up flow), which is also supported by precipitated silica sinter whitish on the surface of the hot water.

Alteration mineral types of the rocks in this area are quartz, aragonite/calcite and feldspar minerals. Petrographic analysis is supported by the XRD method that indicated that the alteration minerals present are generally dominated by the presence of aragonite/calcite with particle size of $0,05-2 \mathrm{~mm}$, the abundance of $55 \%$ and the spread evenly. Based on the presence of aragonite/calcite it can interpret that the origin rock is carbonate. Thus the implication of this research with the presence of alteration minerals dominated by mudstone suggests that the type of hot spring area in Oma-Haruku is a type of reservoir high-temperature, namely $>175^{\circ} \mathrm{C}$, thereby potentially as geothermal field in Central of Moluccas.

Aragonite/calcite are oxide minerals formed by mixing certain elements with hydroxide groups $(\mathrm{OH})$ that is analysis by Specktroscopic FTIR (fourier transform infrared). $\mathrm{OH}$ is at a wave number between 3600-3800 $\mathrm{cm}^{-1}$ which has alcohol/fenol. Beside aragonite/calcite which is a alteration minerals from carbonat clay (mudstone) has a $\mathrm{C}=\mathrm{O}$ funcion group, and is in a value with a wave number $1690 \mathrm{~cm}^{-1}$.

\section{Acknowledgement}

A big thank you addressed to the Dean of the Faculty of Mathematics and Natural Sciences University of Pattimura which helps provide funding and research equipment facilities.

\section{References}

[1] Harvey, CC, 1998, Lectures and seminar on clay minerals, Geothermal Institute, the university of Auckland, New Zealand.

[2] Andayany, H., 2015, Proceeding $1^{\text {st }}$ International Seminar of Basic Science, Faculty Of Mathematics And Natural Science, Pattimura University, Ambon.

[3] Clarence Karr, Jr., 1975, "Infraredad Raman Spectroscopy of lunar and terrestrial minerals", Academic press, New York,1-3.

[4] Silawane, A., 2016, Identification Of Rocks In the Tehoru Hot Spring Area, Central Of Moluccas, Pattimura University, Ambon. 
[5] Ellis, A.J. and Mahon, W.A.J., 1977, Geochemistry and Geothermal System, Academic Press, New York, N.Y., 392 pp.

[6] Sulaeman, B., Asngari and Nuryasin, 2007, Investigation of Akesahu-Tidore Geothermal Geochemistry, North Maluku, Geology Resource Center, Bandung.

[7] Harvey, CC \& Browne, PRL, 1998, Mixed-layer clay geothermometry in the Wairakei geothermal field, New Zealand, Clays \& clay minerals, vol.39 no.6, 614-621.

[8] Herman, D.Z., 2006, Geothermal Potential and Conservative Thought, Center for Geological Resources, Bandung.

[9] Nicholson, K., 1993. Geothermal fluids. Chemistry and exploration techniques. Springer-Verlag Berlin Heidelberg.
[10] Hochstein, M.P. and P.R.L. Browne, 2000, Surface Manifestations of Geothermal System with Volcanic Heat Sources, in Encyclopedia of Volcanoes. 


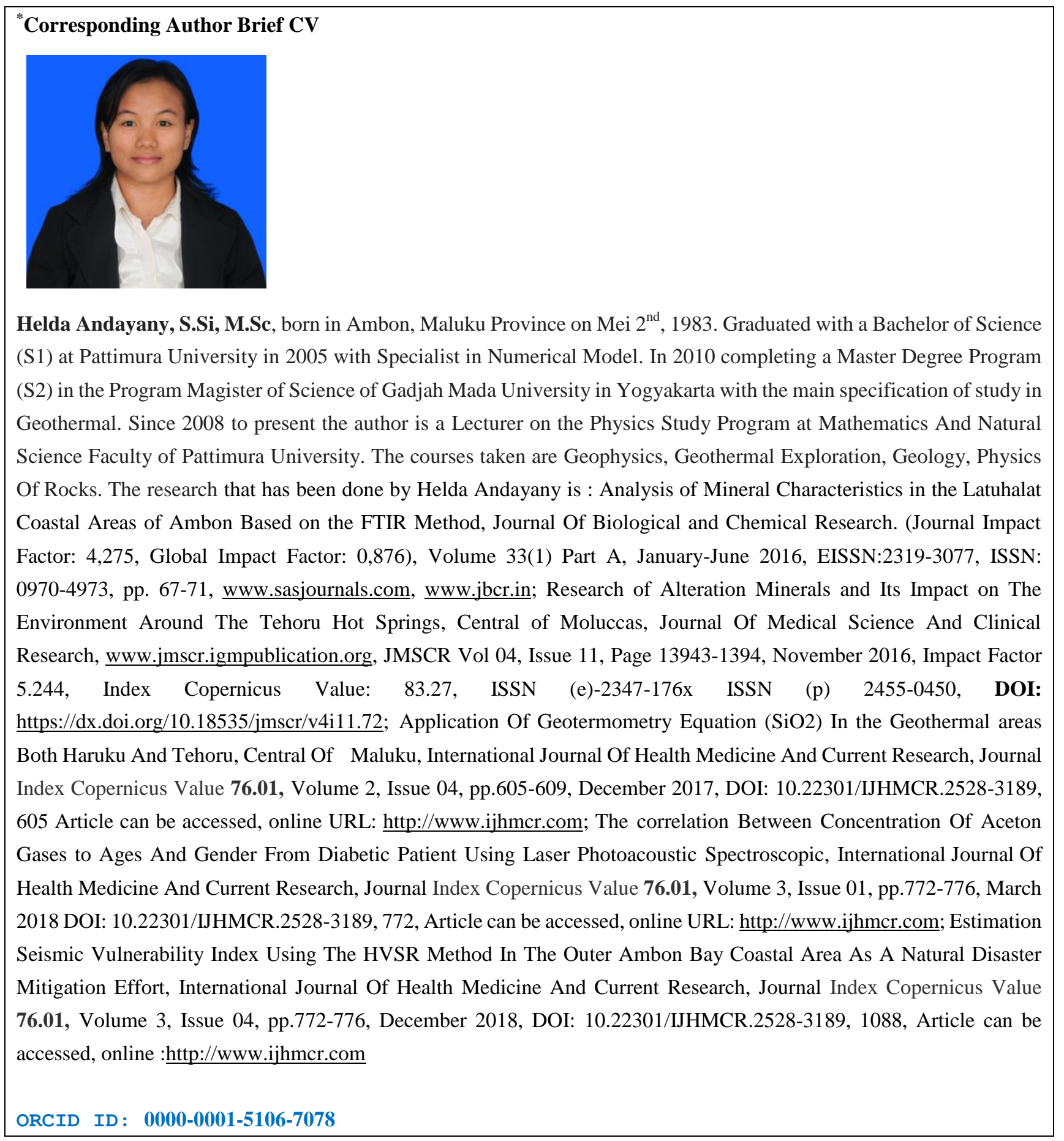




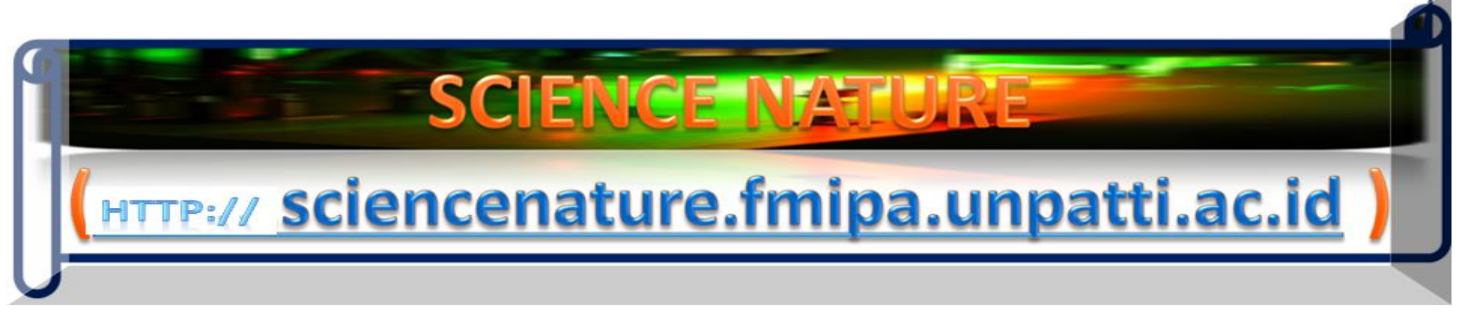

Science Nature 2(2), pp.097-104 (2019)

e-ISSN: 2654-6264

DOI: https://doi.org/10.30598/SNVol2Iss2pp097-104year2019

\title{
Pangi Leaf (Pangium edule Reinw) Herbal Medicine:
}

\section{A Marvelous Candidate for the Prominent HIV Herbal Medicine}

\author{
Arend Mapanawang ${ }^{1 *}$ and Hendry Izaac Elim ${ }^{2-8 \varphi}$ \\ ${ }^{1}$ Department of Pharmacy, College of Health Sciences, Medika Mandiri Foundation, \\ Halmahera,Indonesia \\ ${ }^{2}$ Nanomaterials for Photonics Nanotechnology Laboratory (N4PN Lab.), Department of \\ Physics, Faculty of Mathematics and Natural Sciences, Pattimura University, \\ Jl. Ir. M. Putuhena, Poka, Ambon, Indonesia 97233 \\ ${ }^{3}$ Nanotechnology Research Center and Innovative Creation (PPNRI-LEMLIT), Research \\ Center of Pattimura University, Pattimura University Campus, J1. Mr. CHR. Soplanit, \\ Rumah Tiga, Ambon, Indonesia 97234 \\ ${ }^{4}$ Multidisciplinary Research Center of Excellence(MrCE), \\ UNPATTI, Jl. Chr. Soplanit, RumahTiga, Ambon, Indonesia 97234 \\ Jl. Ir. MartinusPutuhena, Poka, Ambon, Indonesia 97233 \\ ${ }^{5}$ Maritime and Marine Science Center of Excellence (MMSCE) \\ Jl. Dr. Leimena, Ambon, Indonesia 97234 \\ ${ }^{6}$ Theoretical Physics Laboratory, Physics department, Pattimurauniversity, \\ Ambon, Indonesia 97233 \\ ${ }^{7}$ Development and Innovative Center (PPI) of Pattimura University, Indonesia \\ ${ }^{8}$ Electronics and Instrumentation Specific Laboratory (ELINS Lab.), Department of \\ Physics, Faculty of Mathematics and Natural Sciences, Pattimura University, \\ Jl. Ir. M. Putuhena, Poka, Ambon, Indonesia 97233
}

Received : June 1, 2019

Revised : June 12, 2019

Published : June 13, 2019

Copyright @ All rights are reserved by A.L. Mapanawang and H.I. Elim (Elim Heaven)

Corresponding author: "Email: arend_mapanawang@yahoo.com; ${ }^{\mathbf{} E m a i l}$ hendry.elim@ @staff.unpatti.ac.id 


\section{Abstract}

A medicine named as Love herbal (LH) fabricated using zingiberaceae fruit (Golobe halmahera) with a very high concentration ofIC50 $=6.54 \mathrm{ng} / \mathrm{ml}[\mathbf{1 - 6}]$ had been compared with pangileaf (Pangium edule Reinw) as well as the combination of pangi-LH herbal medicine especially in their functions of stopping the growth of HIV virus inside $\mathrm{T}$ Cell with $\mathrm{CD} 4$ in its surface. By using optical spectroscopy techniques of fast Fourier transform infrared (FTIR), photo cells, and gas chromatography mass spectrometer (GCMS), we found their significant differences. Based on our former finding, the inhibition of pangi leaf was $\mathbf{2 . 1 9}$ times larger than that in love herbal medicine [7]. Such pangi leaf medicine has advantages of optical uniqueness behaviors due to $\mathbf{C} \equiv \mathbf{C}$ at $\mathbf{2 2 6 0} \mathbf{~ c m}^{-1}$ which might be closely in conjunction with very strong alkaline function associated with at least 4 compounds ofoctadecanoic acid (24.6\%), squalene (21.22\%), hexadecanoic acid (15.08\%), and phytol (10.33\%) to kill HIV virus more effectively and safely in human body. The results of our observation under real time photo cells with pure pangileaf medicine at concentration of 400 to 800 ppm were superior to $\mathbf{L H}$ medicine. Such output suggests that pangi leaf medicine is very promising for healing HIV patients in the future applications.

Keywords: Love Herbal (LH), Pangileaf, Optical Behavior,

HIV herbal medicine, Anti-cancer.

\section{ARTICLES}

\section{Introduction}

Since the discovery of herbal medicine called as Love herbal (LH) from STIKES Halmahera fabricated using the largest flavonoid content of $6.54 \mathrm{ng} / \mathrm{ml}$ found in zingiberaceae fruit or Golobe Halmahera/ Maluku consisted of at least 5 types of such Golobe called in North Maluku province or Galoba in Maluku province, respectively [1-7],

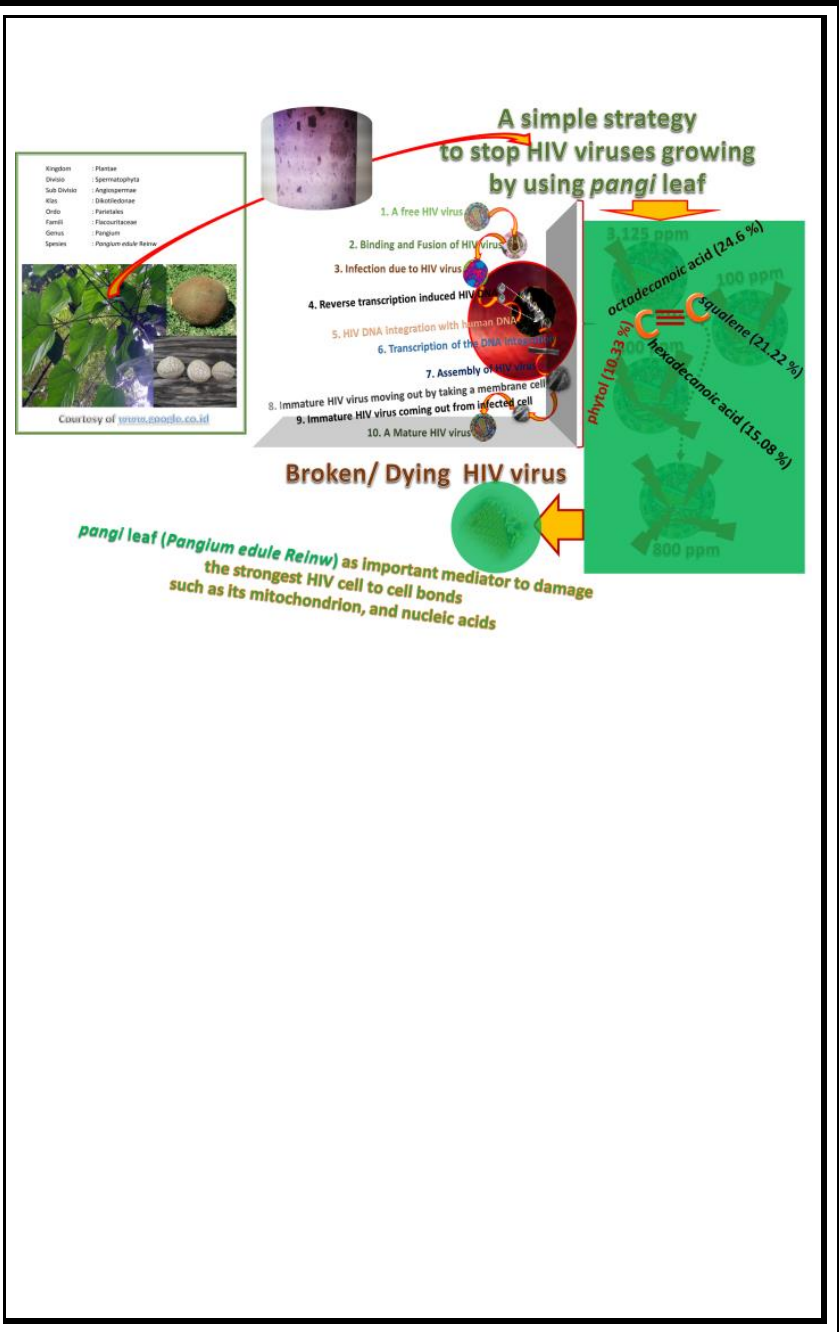

many efforts have been conducted by the authors of Mapanawang and Elim to study it particularly associated with its multitasking healing system which was first introduced by $[5,6]$ based on optical behavior and electronic molecular system [8-10] in order to heal various deceases and parasites such as HIV as well as herbal chemotherapy capsule healing system comparable to cisplatin, a common commercial chemotherapy medicine [11]. In the special case of about $\sim 36$ years mystery of unsolved problem in healing HIV patience since Prof. Francoise Barre-Sinoussi, the nobel 
winner in 2008 due to her first time discovery of the novel virus in her laboratory study in 1982, following by many different detail studies from Prof. Dr. Gallo, and his collaborators in 1984 [12-15], ones therefore would like to improve the former invention of LH medicine [1-11] by incorporating a possibility of the use of pangi leaf (Pangium edule Reinw) herbal medicine.

In this letter, we report for the first time that based on our former discovery in Ref. [11] that due to pangi leaf high inhibition of $94.8 \%$ in stopping the growth of HIV virus via the photo cells observation, a detail optical properties study of the medicine contents related to its chemical bonding is presented as well as its relationship with gas chromatography mass spectrometer (GCMS) detection of its main compounds content. We found that pangi leaf medicine has a great advantage of optical uniqueness behaviors due to $\mathbf{C} \equiv \mathbf{C}$ strong bonding at $2260 \mathrm{~cm}^{-1}$ in comparison with that of LH medicine which might be closely in conjunction with very strong $\mathbf{C} \equiv \mathbf{C}$ alkaline function in conjunction with at least 4 compounds of (i). octadecanoic acid (24.6\%), (ii). squalene (21.22\%), (iii). hexadecanoic acid (15.08\%), and (iv). phytol (10.33\%) to stop growing HIV parasite virus more effectively and safely in human body.

\section{Research Method}

The scientific procedure and design to overcome HIV spreading in CD4 of the surface of $\mathrm{T}$ cell of human being lymphocyte [16] is depicted in Fig. 1 by using at least 10 steps of stopping HIV in the inner part of T cells. In this report, we try to provide our best scientific knowledge without our own laboratories expensive equipment which means that one sent the as fabricated herbal medicines to be investigated independently in few professional scientific laboratories located in main cities of Java, Indonesia such as in Jakarta, Bogor, and Serpong, respectively. After a deep thinking and discussion, the authors are then explained all the data based on the way it is.

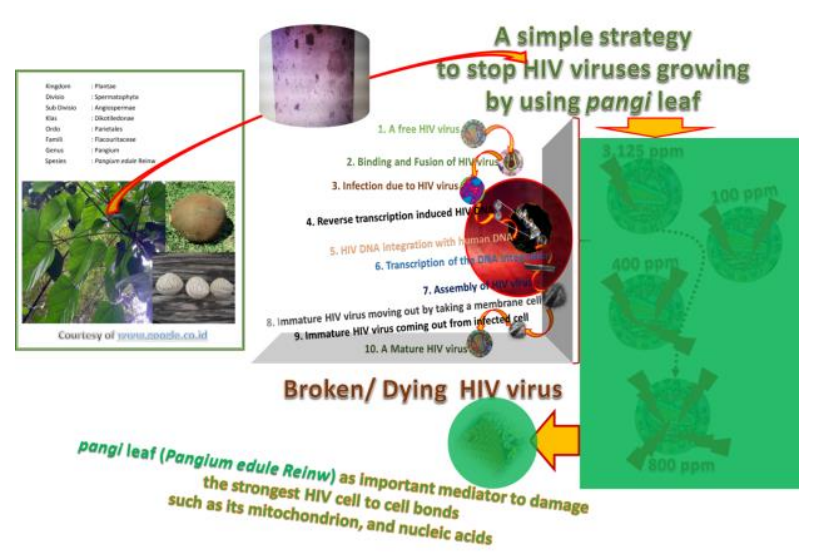

Figure 1. A scientific procedure and design to overcome HIV spread in $\mathrm{T}$ cell of human being using a herbal medicine fabricated using pangi leaf (Pangium edule Reinw). There are at least 10 steps to stop growing the HIV viruses inside T cell.

\section{Results and Discussion}

Figure 2 describes the chemical bonding spectroscopy of pure pangi leaf found in North Maluku/ Sulawesi, Indonesia, and its comparison with a mixture of Golobe Halmahera/ Maluku and pangi leaf measured using a Fourier transform infrared (FTIR) spectrometer, SHIMADZU, Japan of LIPI laboratory, Indonesia. We obtain that pangi leaf medicine has a great advantage of optical uniqueness behaviors due to a significant $\mathbf{C} \equiv \mathbf{C}$ strong bonding at $2260 \mathrm{~cm}^{-1}$ in comparison 
with that of $\mathbf{L H}$ medicine which might be closely in conjunction with very strong $\mathbf{C} \equiv \mathbf{C}$ alkaline function to kill HIV virus without any bad effects in human T cells.

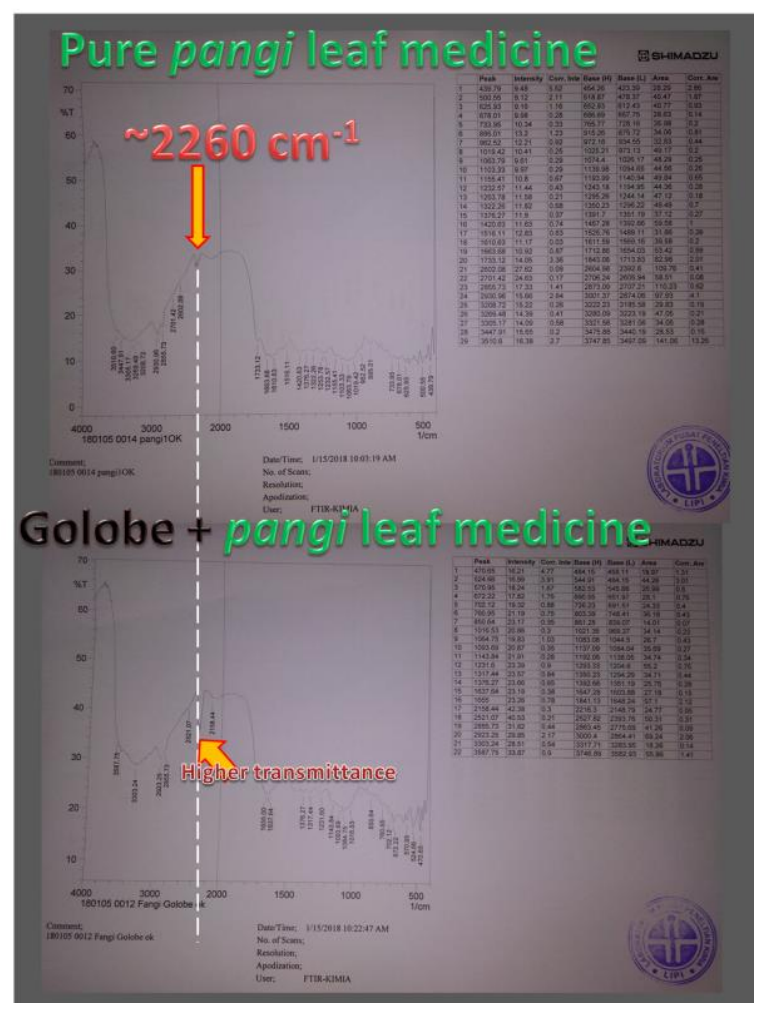

Figure 2. The FTIR response of future prominent HIV medicine character called as pure pangi medicine with the inhibition percentage is about 2.19 times higher than that in $\mathbf{L H}[\mathbf{1 , 1 1}]$ related to the triple bonding of carbon strong absorption at $2260 \mathrm{~cm}^{-1}$.

In investigating on how excellence both types of herbal medicines in curing HIV virus, we carried out a photo cells comparison on the samples in Premata IPB Laboratory, Bogor, West Java province, Indonesia. The results of our real time observation in photo cells with the concentration of 400 to $800 \mathrm{ppm}$ of pure pangi leaf medicine show that more HIV viruses were destroyed in comparison with that of $\mathbf{L H}$ medicine as shown in Fig. 3 and Fig. 4, respectively. Moreover, at a high $800 \mathrm{ppm}$ concentration of pure pangi leaf medicine, there were more HIV viruses destroyed in comparison with that of $\mathbf{L H}$ medicine. This is in agreement with our former inhibition study in Ref. $[8,11]$ that pangi leaf had 2.19 times larger inhibition than that in $\mathbf{L H}$ medicine.

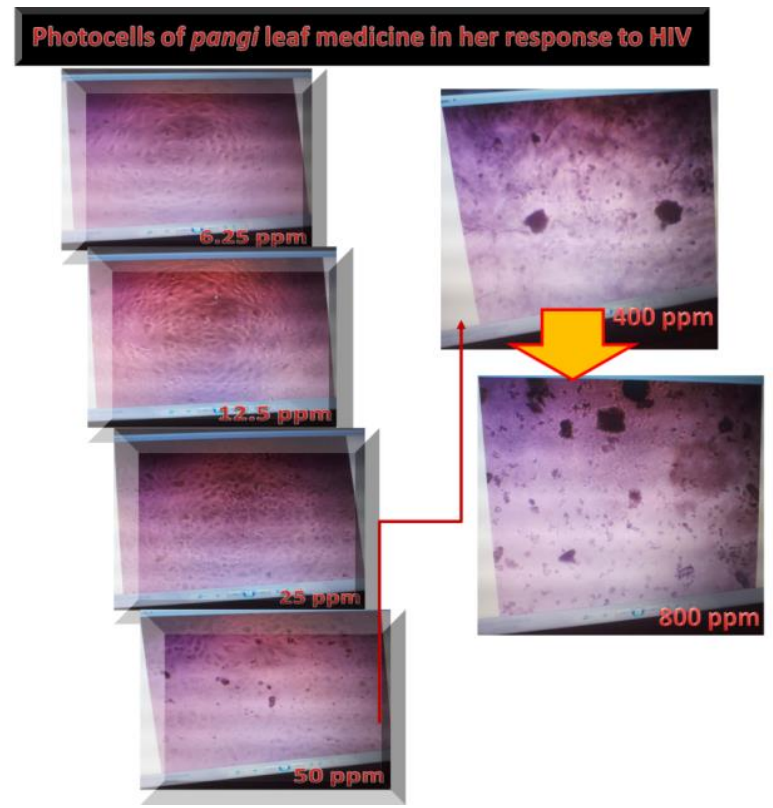

Figure 3. Photo cells observation on how pangi leaf medicine with different concentrations stopped growing HIV virus. It should be noticed that as the concentration of pangi leaf medicine reached $400 \mathrm{ppm}$ to $800 \mathrm{ppm}$, the HIV virus were getting destroyed completely.

Figure 5 shows that there are $\mathbf{1 5}$ substances in pangi leaf herbal medicine measured using gas chromatography mass spectrophotometer (GCMS). From the 15 substances, ones discovered there were four significant largest compounds contributing to the medicine healing process especially in handling HIV virus as described in Fig. 4, involving (i). octadecanoic acid (24.6 \%), (ii). squalene (21.22\%), (iii). hexadecanoic acid (15.08\%), and (iv). phytol (10.33 \%), respectively. 


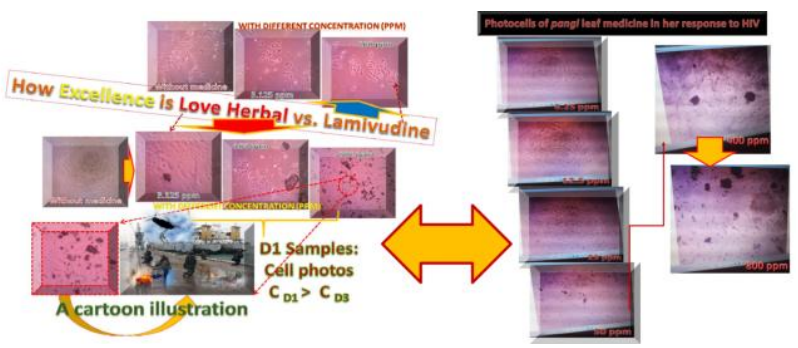

Figure 4. A comparison between the photo cells observation of LH medicine and pangi leaf medicine when both types of herbal medicines were at the same concentration of $800 \mathrm{ppm}$, the HIV viruses seemed destroyed. However, when ones enlarged the view of the photo cells of LH medicine treatment to HIV virus, there were still some HIV viruses were alive. In this case, the pangi leaf herbal medicine was much better impacts to stop HIV growing, and even completely destroyed it all.

The physical chemistry chemical physics behavior of such complicated compounds associated with $\mathbf{C} \equiv \mathbf{C}$ strong absorption bonding at $2260 \mathbf{~ c m}^{-1}$ as depicted in Fig. 2 was investigated based on a multidisciplinary former works in Ref. [11, 17-21]. These findings are a gateway opportunity to improve future nanochip medicine as illustrated in Ref. [22-23].

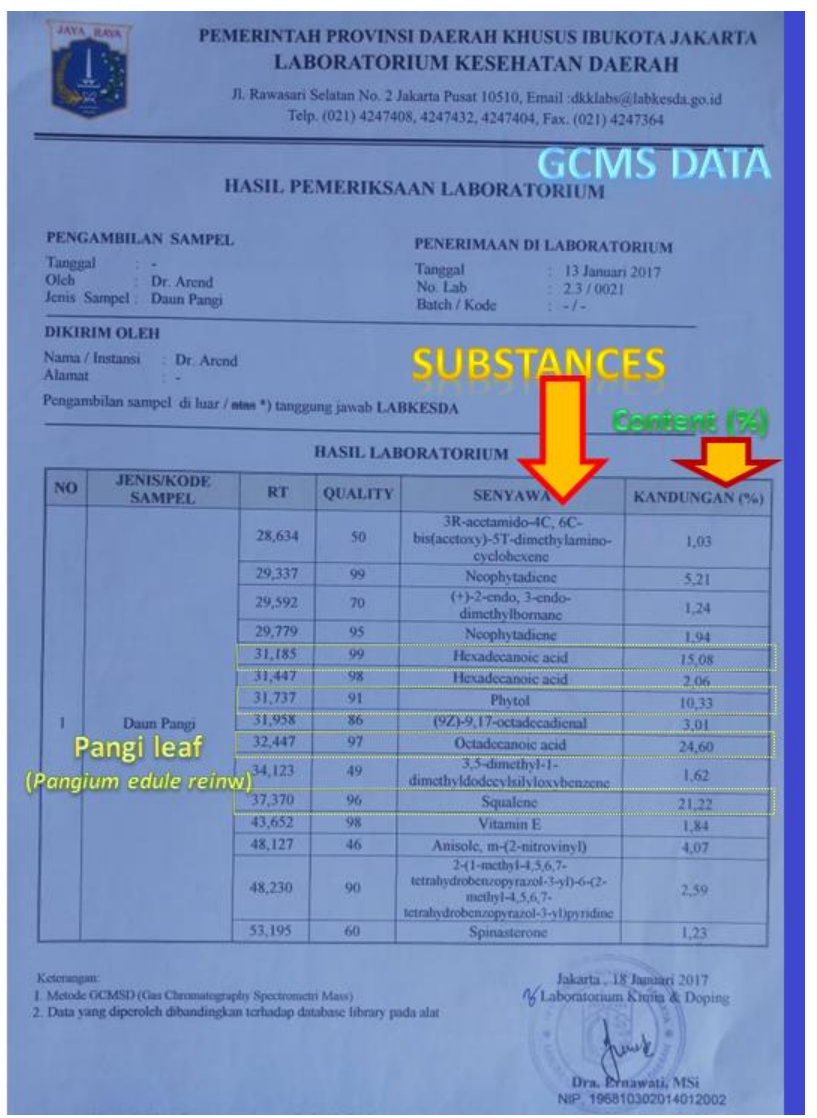

Figure 5. Original data of GCMS measurement results of pangi leaf herbal medicine dated on $18^{\text {th }}$ January 2017. There are at least 4 main compounds contributing to the medicine such as octadecanoic acid (24.6\%), squalene (21.22\%), hexadecanoic acid (15.08\%), and phytol $(10.33 \%)$, respectively. The original data measured from another professional laboratory was provided as it is just like "a scientist is more important than his excellent equipment".

\section{Conclusion}

In conclusion, a novel prominent herbal medicine fabricated by pangi leaf has been studied using at least three main experiment systems of FTIR chemical bonding, photo cells, and GCMS investigations. We obtained that the herbal medicine is superior to $\mathbf{L H}$ medicine due to its high inhibition of 2.19 times larger than $\mathbf{L H}$ medicine. Such 
superiority was contributed by $\mathbf{C} \equiv \mathbf{C}$ strong absorption bonding at $2260 \mathrm{~cm}^{-1}$ in conjunction with 4 largest compounds of (i). octadecanoic acid, (ii). squalene, (iii). hexadecanoic acid, and (iv). Phytol. This discovery is very promising for the future for healing system for HIV patients based on a deeper knowledge of this interesting herbal medicine discovery.

\section{Acknowledgement}

H.I.E is cordially grateful to thank Prof. Dr. M.J. (Nus) Saptenno, one of the innovative president of Pattimura university due to his open minded and wide insight in expanding both research work and business since it was built on $23^{\text {rd }}$ April 1963. Part of this work was supported by a research grant of RisetUnggulan DaerahNo. 741/UN13/SK/2017 about novel energy research funded by Pattimura university, Ambon, Indonesia to the head of Nanotechnology Research Center and Innovative Creation (PPNRI, URL: http://lppm.unpatti.ac.id/pusat-pnri) since it was built on $24^{\text {th }}$ April 2015 with Rector Prof. Thomas Pentury' official letter No. 65/UN13/SK/2015. Moreover, the frontier research work of H.I.E was supported from a world class research (WCR) grant about future creative energy sources supported by Indonesia Ministy of Higher Education (Ristek-Dikti) in the year period of 2019 to 2021.

\section{Conflicts of interest}

Both authors in this paper have no conflict of interest because they are working under a good collaboration to improve the development of science and technology in particular areas of both North Maluku and Maluku provinces.

\section{References}

[1]. H.I. Elim and A.L. Mapanawang, THE ATTRACTIVE DIFFERENCES OF TWO TYPES OF HERBAL MEDICINE FROM ZINGIBERACEAE FRUIT (GOLOBE HALMAHERA),
International Journal of Health Medicine and Current Research 3 (01), 799-806 (2018).

[2]. H.I. Elim and A.L. Mapanawang, Electronics physical system of large antioxidant structure in herbal medicine based Zingiberaceae fruit: Understanding and application, J. Nanomed. \& Nanotech. Vol. 9, p. 65 (Abstract \& Biography) (2018).

[3]. H.I. Elim and A.L. Mapanawang, Electronics physical system of large antioxidant structure in herbal medicine based Zingiberaceae fruit: Understanding and application, Nano Tech Appl. 1(1), pp. 1-4 (2018).

[4]. H.I. Elim, Scientific Breakthrough Based on Natural Creation: "1 Diamond with 7 Eyes", COJ Reviews and Research Vol. 1(1), pp.1-4 (2018).

[5]. H.I. Elim, Physics of Multitasking Nanomedicine, IJHMCR (http://www.ijhmcr.com) 2 (03), 509-519 (2017).

[6]. H.I. Elim, Nanomedicine with Its Multitasking Applications: A View for Better Health, IJHMCR 2 (02), 353-357 (2017).

[7]. H.I. Elim, The Discovery of NEW Golobe and Its Amazing Healing System, Science Nature 2(1), pp. 66-70 (2019). e-ISSN 2654-6264.DOI: https://doi.org/10.30598/SNVol2Iss1pp066-070y2019.

[8]. H.I. Elim, Nonlinear Optics and the Frontier of Nanoscience and Nanotechnology, Pattimura University Press, pp. 1-144 (2018). ISBN： 987-602-61906-9-7.

[19]. A.L. Mapanawang and H.I. Elim, Chemical bonding characters of love herbal medicine, J. Nanomed. \& Nanotech. Vol. 9, p. 63 (Abstract \& Biography) (2018).

[10]. A.L. Mapanawang and H.I. Elim, Chemical Bonding Character of Love Herbal Medicine: A Prominent Medicine Candidate for Preventing HIV Virus, Nano Tech Appl. 1(1), pp. 1-5 (2018).

[11]. A.L. Mapanawang and H.I. Elim, Unique Chemical Bonding Behavior of Love Herbal Medicine and Its Conjunction with Chemotherapy Drug, J. Nanomedicine and Nanotechnology 9(3), 1000503 (2018).

[12]. R.C. Gallo, S.Z. Salahuddin, M. Popovic, G.M. Shearer, M. Kaplan, B.F. Haynes, T.J. Palker, R. Redfield, J. Oleske, B. Safai, G. White, P. Foster, and P.D. Markham, Frequent Detection and Isolation of Cytopathic Retroviruses (HTLV-III) from Patients with AIDS and at Risk for AIDS, Science 224 (4648), 500-503 (1984).

[13]. M. Popovic, M. G. Sarngadharan, E. Read, and R.C. Gallo, Detection, Isolation, and Continuous Production of Cytopathic 
Retroviruses (HTLV-III) from Patients with AIDS and Pre-AIDS, Science 224 (4648), 497-500 (1984).

[14]. M.G. Sarngadharan, M. Popovic, L. Bruch, J. Schüpbach, and R.C. Gallo, Antibodies Reactive with Human T-Lymphotropic Retroviruses (HTLV-III) in the Serum of Patients with AIDS,

Science 224 (4648), 506-508 (1984).

[15]. J. Schüpbach, M. Popovic, R.V. Gilden, M.A. Gonda, M.G. Sarngadharan, and R.C. Gallo, Serological Analysis of a Subgroup of Human T-Lymphotropic Retroviruses (HTLV-III) Associated with AIDS, Science 224 (4648), 503-505 (1984).

[16]. G. Wang, M.L. McCain, L. Yang, A. He, F.S. Pasqualini, A. Agarwal, H. Yuan, D. Jiang, D. Zhang, L. Zangi, J. Geva, A.E. Roberts, Q. Ma, J. Ding, J. Chen, D.-Z. Wang, K. Li, J. Wang, R.J.A. Wanders, W. Kulik, F.M. Vaz, M.A. Laflamme, C.E. Murry, K.R. Chien, R.I. Kelley, G.M. Church, K.K. Parker, and W.T. Pu, Modeling the mitochondrial cardiomyopathy of Barth syndrome with induced pluripotent stem cell and heart-on-chip technologies, Nature Medicine 20, 616-623 (2014).

[17]. D.M. Margolis, J.V. Garcia, D.J. Hazuda, and B.F. Haynes, Latency reversal and viral clearance to cure HIV-1, Science353 (6297), p. 262, aaf6517-1 - aaf6517-7 (2016).

[18]. I. Ohsawa, K. Yamagata, M. Ishikawa, K. Takahashi, M. Watanabe, K. Nishimaki, K.-I. Katsura, Y. Katayama, S. Asoh, and S. Ohta, Hydrogen acts as a therapeutic antioxidant by selectively reducing cytotoxic oxygen radicals, Nature Medicine 13, 688-694 (2007).

[19]. L. Paris, R. Magni, F. Zaidi, R. Araujo, N. Saini, M. Harpole, J. Coronel, D.E. Kirwan, H. Steinberg, R.H. Gilman, E.F. Petricoin III, R. Nisini, A. Luchini, and L. Liotta, Urine lipoarabinomannan glycan in HIV-negative patients with pulmonary tuberculosis correlates with disease severity, Sci. Transl. Med. 9, eaal2807 (2017).

[20]. Y. Liu, J. Sheng, A. Fokine, G. Meng, W.-H. Shin, F. Long, R.J. Kuhn, D. Kihara, and M.G. Rossmann, Structure and inhibition of EV-D68, a virus that causes respiratory illness in children, Science 347 (6217), 71-74 (2015).

[21]. Y. Yin, B. Manoury, and R. Fåhraeus, Self-Inhibition of Synthesis and Antigen Presentation by Epstein-Barr Virus-Encoded EBNA1, SCIENCE 301, 1371-1374 (2003).
[22]. H.I. Elim, A.L. Mapanawang, and M.V. Reddy, A Creative Proposal to Improve Woman and Child Health: from the Knowledge of Physical Nanoscience to Nanotechnology Implementation and Products, CPQ Women and Child Health 1 (6), pp. 1-11 (2019).

[23]. H.I. Elim and L.Y. Chiang, Nanochip Medicine: Physical Chemistry Engineering, Science Nature 2(1), pp. $86-89$ (2019). DOI: https://doi.org/10.30598/SNVol2Iss1pp086-089y2019. 


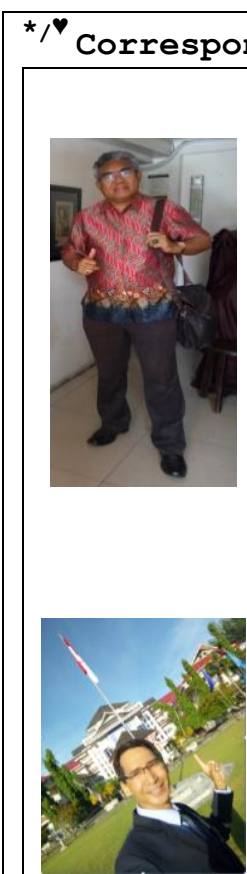

*Dr. dr. Arend I. Mapanawang, Finasim is a very experienced director of Health Medical College called as STIKES Halmahera in Halmahera island located in North of Maluku, Indonesia. Dr. Arend is recently the Editor-in-Chief (EIC) of reputed International Journal of Health Medicine and Current Research (WWW.IJHMCR.com) indexed by Web of Science (WoS) since 2019. He is an internist doctor as well as an Indonesia scientist in herbal medicine including for the curing of malaria, HIV virus, and hepatitis with more than 20 years experiences. He had written various books including history and the cause of world wars books. His publications in various international journals have made him as a prominent invited speaker in the world such as in South Korea, United Kingdom, USA, and Germany. As a matter of facts, Dr. Arend is now one of the best scientist in North Maluku province.

Assoc.Prof. (Lektor Kepala) Hendry Izaac Elim, Ph.D is a young Indonesia scientist from Pattimura university (UNPATTI) with the rank $23^{\text {rd }}$ in 2017 based on Webomatrics (http://www.webometrics.info/en/node/96), or the $3^{\text {rd }}$ rank best Indonesia physicist in this $21^{\text {st }}$ century based on the SINTA data, RistekDikti in 2019. Prof. Elim is now a head of the Nanotechnology Research Center and Innovative Creation (PPNRI-LPPM, website: http://lemlit.unpatti.ac.id/pusat-pnri) of the Pattimura University (UNPATTI) as well as Chairman for Nanomaterials for Photonics Nanotechnology Laboratory (N4PN Lab), Physics Department, Faculty of Mathematics and Natural Sciences (FMIPA-UNPATTI), Ambon, Indonesia. He has been very active in the following scientific members of the Indonesia Theoretical Physicist, and MRS Indonesia. Due to his strong background of his B.Sc (S.Si) in Theoretical Physics in 1995 at Gadjah Mada university (UGM), and M.Si (M.Sc) in Theoretical Physics of Institut Teknologi Bandung (ITB) in 1999, he was successful in obtaining his Ph.D in the field of physics of nanoscience and nanotechnology, at National University of Singapore (NUS), Singapore on $13^{\text {th }}$ December 2005 . As soon as he finished his Ph.D, he was offered a postdoctoral position at NUS until September 2007, and then moved to IMRAM, Tohoku university, Sendai, Japan as research assistant professor for about 4.5 years. Dr. Elim research group at PPNRI-LPPM at Pattimura university was started on $\mathbf{2 4}^{\text {th }}$ April 2015 by educating his first 6 research B.Sc students. Since that triggered time, he already educated more than 60 graduated B.Sc up to 2019 in the fields of superfibers, bio-membranes, and herbal medicine as well as nanobattery system. Prof. Elim had been recently invited to give international scientific talks in prestigious 2018 PharmaNano in Las Vegas, and 2019 PharmaNano in New York as well as many quest lectures associated with the multitasking applications of physics in nanoscience and nanotechnology in many national universities such as University of Pelita Harapan, UNPATTI, Universitas Negeri Manado (UNIMA), Universitas Sam Ratulagi (UNSRAT), STIKES Halmahera, AKBID MAKARIWO, and University of Indonesia. According to Web of Science and Publons data, Prof. Elim has published over 70 papers with h-index of 23, and citation more than 2260. Moreover, Dr. Elim is recently a member of top scientific society such as AAAS (ID No. 41737449) since 2017-present, and ACS (ID No. 31447106) in 2018-2019. 


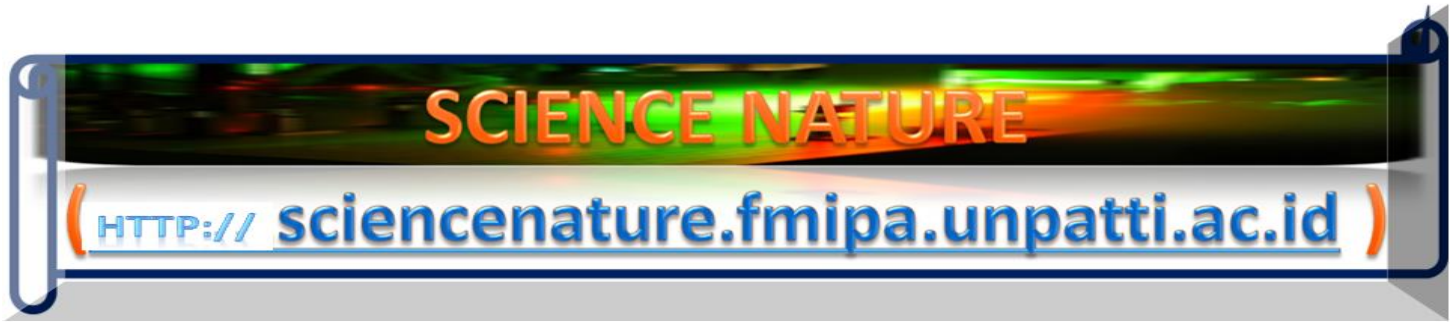

Science Nature 2(2), pp.105-113 (2019)

e-ISSN: 2654-6264

DOI: https://doi.org/10.30598/SNVol2Iss2pp105-113y2019

\title{
Customary Law Associated with Five Integrated Aspects in
}

\author{
Developing Traditional Coastal and Marine Protections for
}

\section{Improving Social People Life and Natural Products in Aru}

\section{Islands Region of Maluku Province, Indonesia}

Martinus J. Saptenno ${ }^{1 *}$, Sostones Sisinaru ${ }^{1}$, Edwin Ubwarin ${ }^{1}$, William A. Siahaya ${ }^{2}$, and Hendry Izaac Elim ${ }^{3-8 \#}$

${ }^{1}$ Law Faculty, Pattimura University, Jl. Ir. M. Putuhena, Poka, Ambon, Indonesia 97233

${ }^{2}$ Faculty of Agriculture, Pattimura University,J1. Ir. M. Putuhena, Poka, Ambon, Indonesia 97233

${ }^{3}$ Nanomaterials for Photonics Nanotechnology Laboratory (N4PN Lab.), Department of

Physics, Faculty of Mathematics and Natural Sciences, Pattimura University,

Jl. Ir. M. Putuhena, Poka, Ambon, Indonesia 97233

${ }^{4}$ Nanotechnology Research Center and Innovative Creation (PPNRI-LEMLIT), Research

Center of Pattimura University, Pattimura University Campus, J1. Mr. CHR. Soplanit,

Rumah Tiga, Ambon, Indonesia 97234

${ }^{5}$ Multidisciplinary Research Center of Excellence(MrCE), UNPATTI, Jl. Chr. Soplanit, RumahTiga, Ambon, Indonesia 97234

${ }^{6}$ Theoretical Physics Laboratory, Physics department, Pattimurauniversity, Ambon, Indonesia 97233

${ }^{7}$ Development and Innovative Center (PPI) of Pattimura University, Indonesia

${ }^{8}$ Laboratory of Electronics and Instrumentation (ELINS Lab,), Physics Department, Pattimura University, Ambon, Maluku, Indonesia 97233

Received : February 22, 2019

Revised : June 6, 2019

Published : June 13, 2019

Copyright @ All rights are reserved by Martinus J. Saptenno, et al.

Corresponding author: "Email: " 


\section{Abstract}

In present on going work, we report the frontier interdisciplinary findings about customary law associated with five integrated aspects such as (1). History, (2). Laws, (3). Culture, (4). Science, and (5). Geoscience (or earth and space science) connected directly to the development of traditional coastal and marine protection to improve social people life in Aru region of $~ 804$ small islands with its highest average hills of $\sim 50$ meter, south east part of Maluku province, Indonesia. The 5 integrated aspects were then investigated to be associated with a system of 6 customary actions as follows: (1). Features, (2). Characters, (3). Connectivity, (4). Sustainable development, (5). Similarity, and (6). Attitudes. Each of these 6 customary actions was very close to an indicator of social people daily lives such as (1) novel idea, (2) services, (3) tradition, (4) social interactions and (5) protections, except for the sustainable development which has been in conjunction with 2 indicators of economy impacts and building strength. The data was collected, identified, and then analyzed by using direct questioner consisted of 50 questions each in 2 different villages of Wokam and Karang Guli. These findings suggest that customary laws practiced traditionally in Aru region are rich or benefits to improve the local people income in order to sustain their traditional coastal and marine life. The research discovery in this simple paper may be applicable to many different fields of study such as in (1) science, (2) engineering and (3) medical practice based on its significant finding of the different between international customary law and the basic principle and essential of customary law.

Keywords: History, Customary Law, Culture, Science, Geoscience, Interdiciplinary. 


\section{ARTICLES}

\section{Introduction}

Conducting a breakthrough research work in social sciences associated with interdisciplinary fields [1-4] was very tough due to the compulsory needs of many different types of scientists to sit down together discussing a novel idea for improving social, customary, economy, and politics (SCEP) status of ordinary society [5] especially those who leave in complex small islands areas like Indonesia country in general with about 14,480 islands, and Maluku province in a particular as a prototype of it with $\sim 1340$ small physical beauty islands associated obviously with realism, idealism, dualism, and logical positivism in natural conservation laws [6-8]. In addition, a serious critics of the implementation of customary law (CL) in society, for example in the south part of Africa [9], as well as a complex debate of the understanding related to conceptual confusion and methodological deficiencies into $\mathbf{C L}$ in the international knowledge currently has received attentions among social scientists [10-12], for instance between J.L. Blutman [10], and A.T. Guzman and J. Hsiang [11]. In addition, the differences of different country with different regulations of the customary laws were also found in Indonesia and Malaysia, even though their geography are like a very close neighbor $[\mathbf{1 4 , 1 5}]$.

In this paper, the researchers provide the best thought on how CL Associated with 5 integrated aspects consisted of (1). History, (2). Laws, (3). Culture, (4). Science, and (5). Geoscience (or earth and space science) in developing traditional coastal and marine protections for improving social people life and natural products in Aru Islands Region of Maluku Province, Indonesia.
Furthermore, such interdisciplinary collaborative contributions can distinguish the significant difference between the position of customary international law (CIL) and their findings on a local wisdom traditional customary law (LWT-CL). The detail explanations and its implementation are explained in this letter.

\section{Research Method}

The technique carried out in this multidisciplinary research work was based on direct survey via a hybrid research method consisted of scientific observation by public airplane trip and satellite images as well as direct observation in the fields to Aru islands region conducted by Pattimura physicist and agriculture scientist as depicted in Fig. 1, and knowledgeable questioner derived by Pattimura university law experts to the village leaders. There were 50 questions in our direct questioner survey among 2 suggested villages of Wokam and Karang Guli from the district leader (Camat), Mr. Roby in the region of Aru islands consisted of three general parts of natural logic as follows:

(i). The first 14 questions were about the customary laws of local people

(ii). The second 18 next questions were about rejections of local people voices due to certain people business policies related to local government improvement aims, and

(iii).The last 18 last questions were about Monitoring and Evaluation (ME) and Novel Findings for solution.

Figure 2 and Fig. 3 show how the interdisciplinary researchers were taking the research data directly to the target by following a systematic research procedure and techniques, respectively. Figure 2 indicates that there were 8 initial steps 
Customary Law Associated with Five Integrated Aspects in Developing Traditional Coastal and Marine Protections for Impraving Sacial People Life and Natural Products in Aru Islands Region of Maluku Province, Indonesia

research procedures embedded on the figure to get permission from local government for research purposes so that the data collections in the target fields will have no any misunderstanding of local leaders.

On the other hand, Fig. 3 shows 9 steps of research technique depicted inside the picture to collect specific data on correct targets based on the prepared 50 questions in the questioner for the village leaders of Wokam and Karang Guli (meaning Head Crown of local language) areas, respectively.

Based on the interdisciplinary systematic works mentioned above, the researchers have obtained the results and its discussion in session 3 of this paper.

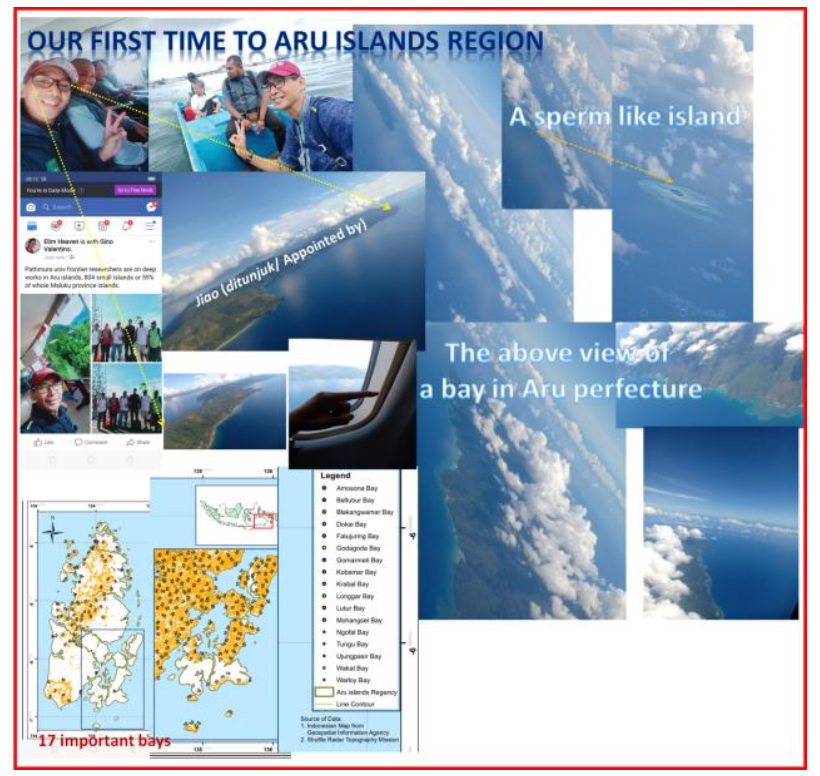

Figure 1. Aru islands region with her 17 important bays taken from the skies using airplane, and visited with local boat particularly in two important villages of Wokam and Karang Guli located very close to the main Dobo city, as well as its high of hills were no higher than 50 meter measured from satellite and recorded in geospatial center (BIG-Maluku) of Pattimura university.

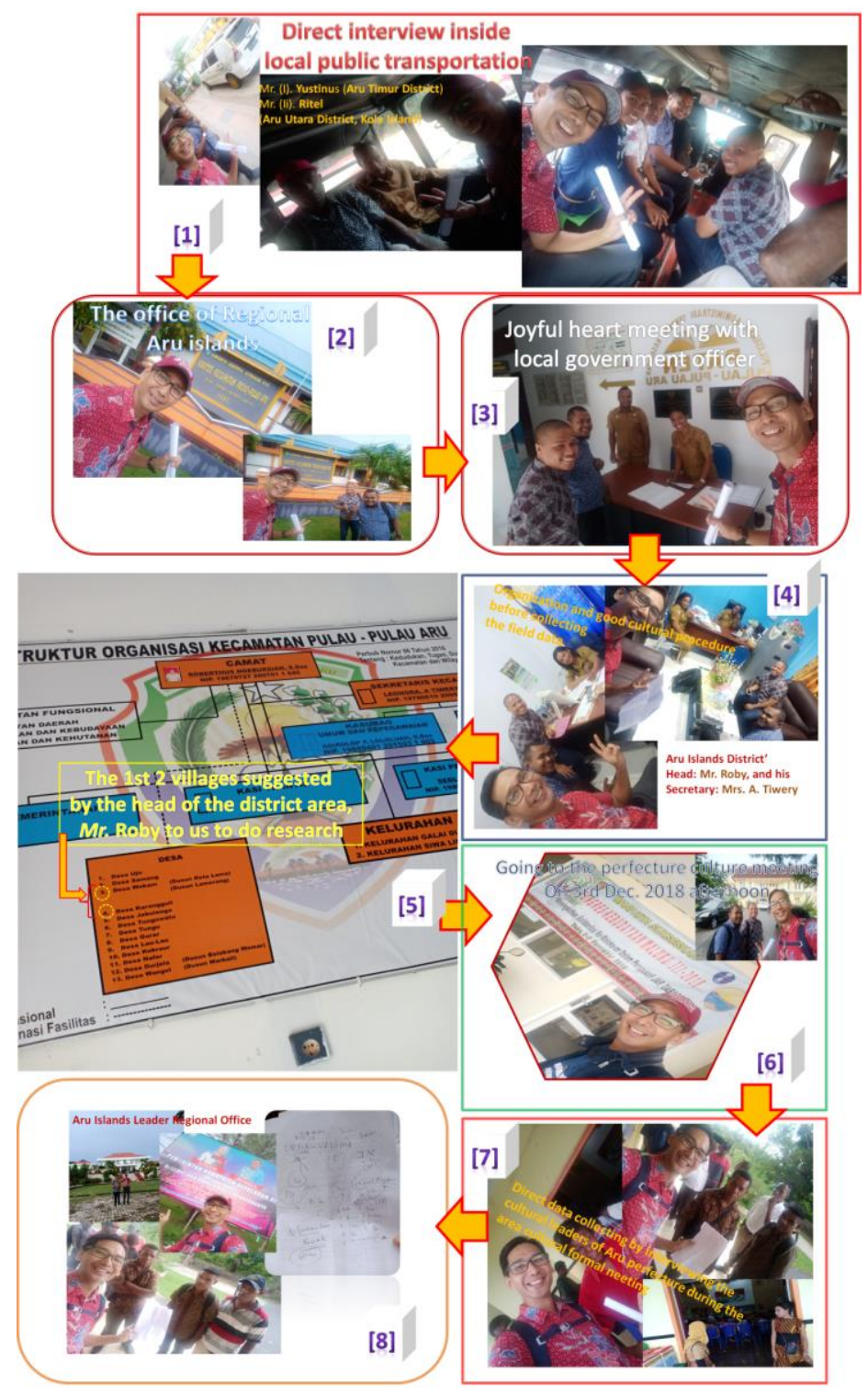

Figure 2. The 8 initial steps research procedures to get permission from local government for research purposes for further data collection in the target fields of local areas. 
Customary Law Associated with Five Integrated Aspects in Developing Traditional Coastal and Marine Protections for Improving Social People Life and Natural Products in Aru Islands Region of Maluku Province, Indonesia

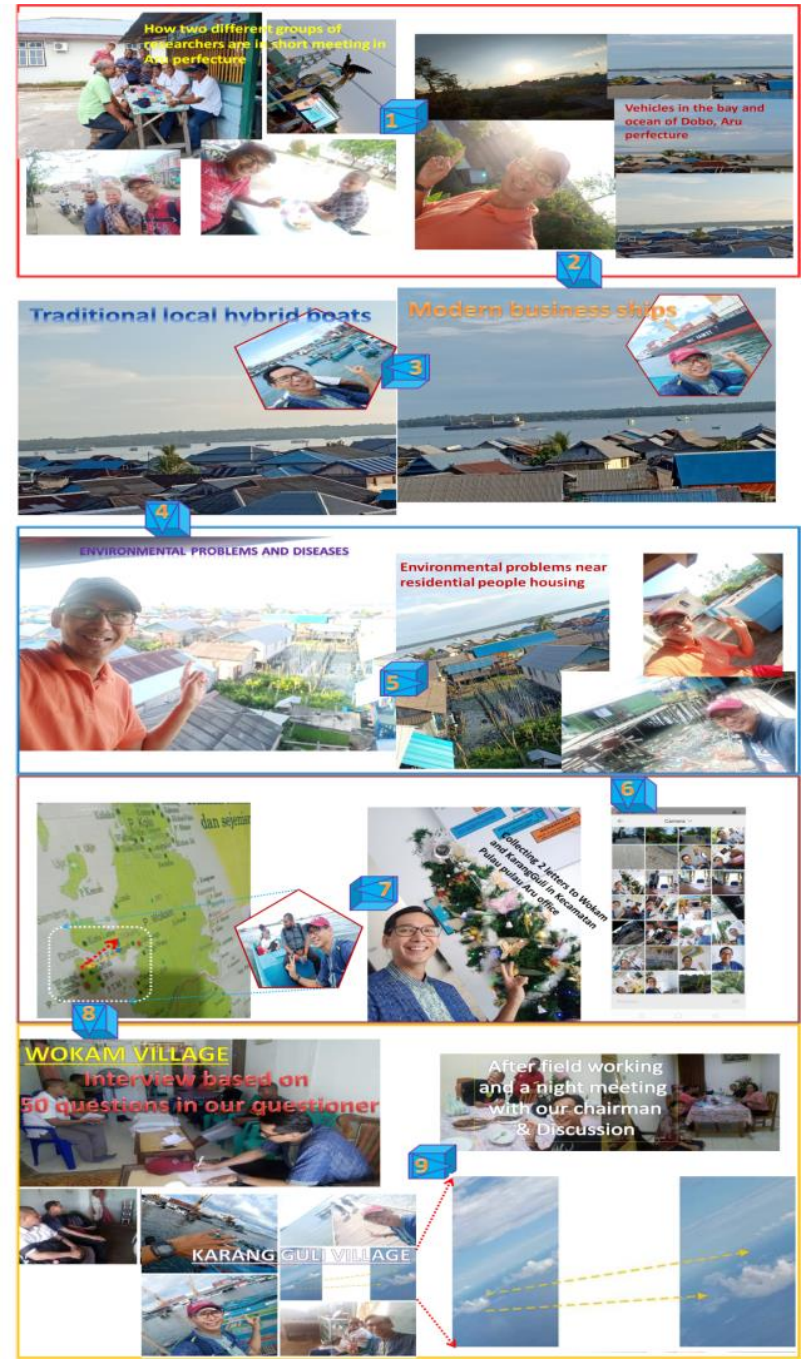

Figure 3. Research technique with 9 steps to collect specific data on target based on the 50 questions in the prepared questioner for Wokam and Karang Guli (meaning Head Crown of local language) villages, respectively. The observed Head Crown in the cloud before our investigation taken from the airplane was shown in the inset

\section{Results and Discussion}

Figure 4 shows an ongoing work in conjunction with customary law associated with five integrated aspects observed in local society of Aru islands region in particular from 2 closest villages of Wokam and Karang Guli from her main city of Dobo as follows: (1). History, (2). Laws, (3). Culture, (4). Science, and
(5). Geoscience (or earth and space science). These 5 significant aspects are clearly linked with the development of traditional coastal and marine protection to improve social people life in Aru region of $\sim 804$ small islands with its highest average hills of 50 meter, south east part of Maluku province, Indonesia. Moreover, such 5 integrated aspects were then investigated and extracted to be mainly connected to a compact system consisted of $\mathbf{6}$ customary actions such as: (1). Features, (2). Characters, (3). Connectivity, (4). Sustainable development, (5). Similarity, and (6). Attitudes. While each of these $\mathbf{6}$ customary actions was very closely to an indicator of social people daily lives involving their contributions in: (1) novel idea, (2) services, (3) tradition, (4) social interactions and (5) protections, except for the sustainable development which has been in conjunction with 2 indicators of (1) economy impacts and (2) building strength. The researchers called this finding as a local wisdom traditional customary law (LWT-CL), which must be protected by Indonesia government law.

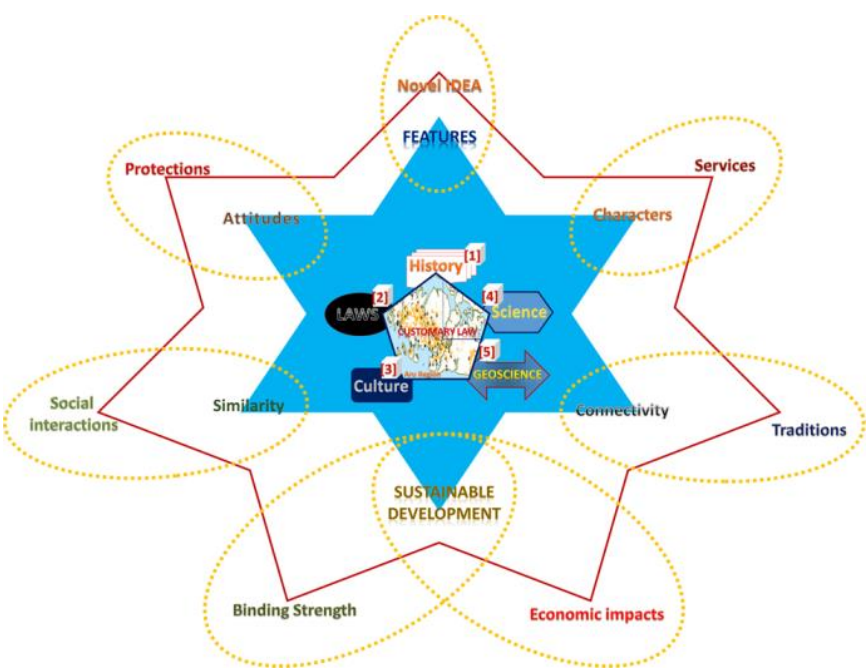

Figure 4. Customary law associated with five integrated aspects of (1). History, (2). Laws, (3). Culture, (4). Science, and (5). Geoscience (or earth and space science) in developing traditional coastal and marine protections for improving social people life and natural products in Aru islands district of about 804 islands in Maluku province, Indonesia. 
Customary Law Associated with Five Integrated Aspects in Developing Traditional Coastal and Marine Protections for Improving Social People Life and Natural Products in Aru Islands Region of Maluku Province, Indonesia

Figure 5 describes a systematic local wisdom based on their language of the first 10 numbers. Number 5 was called as Ur-Lima, while number 10 as $U r$ in which the word "lima" meaning no. 5 in Indonesia language was deleted. Such logic may be translated that there was 5 inside an empty 10 space so that when Ur-Lima become $U r$, there was only pure 10. It is an interesting idea, isn't it?. Another origin of the other numbers shall be in needs of further investigations.

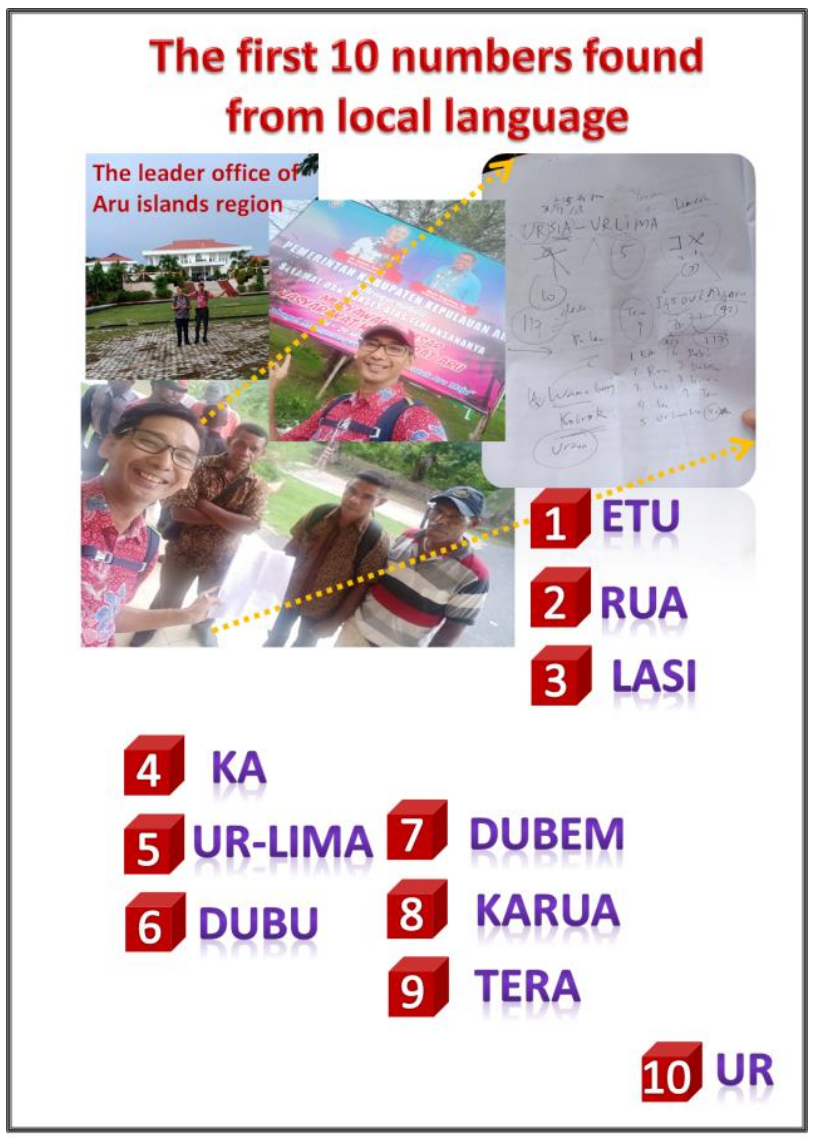

Figure 5. The first 10 numbers found in local language during a direct interview of local leaders when there was a closing ceremony of official customary social meeting in Dobo city, Aru islands region.

The data depicted in Fig. 6 shows how the interdisciplinary researchers of a combination between scientist (physicist) and law social scientists on their contributed duty during their research time in Dobo city sharing particularly to the local scholars who are pursuing their higher degree in the branch of Pattimura university inside Dobo city, the capital city of Aru islands region. The sharing was aimed to educate the young local scholars in order to open their mind and insight based on the data collected, identified, and then analyzed by using direct questioner consisted of 50 questions each in 2 different villages of Wokam and Karang Guli. These findings suggest that customary laws practiced traditionally in Aru region were rich both supranatural and natural resources which are benefits to improve the local people income in order to sustain their traditional coastal and marine life especially to their customary law (sasi) of high quality and value lobsters and sea cucumbers, respectively. The research discovery in this simple finding may be applicable to many different fields of study such as in (1) science, (2) engineering and (3) medical practice based on its significant finding of the different between CIL and the basic principle and essential of customary law obtained in LWT-CL.

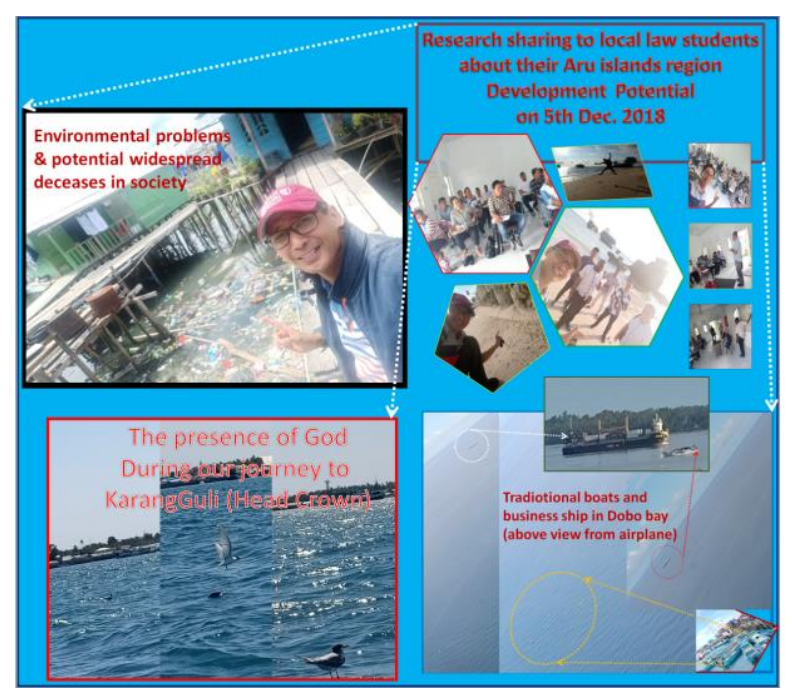

Figure 6. Research sharing based on the facts and data evident in Wokam and Karang Guli villages mostly extracted from both supranatural (the presence of GOD) and applicable LWT-CL found in the villages. 
Customary Law Associated with Five Integrated Aspects in Developing Traditional Coastal and Marine Protections for Improving Social People Life and Natural Praducts in Aru Islands Region of Maluku Province, Indonesia

Finally, Fig. 7 explains the differences between CIL and LWT-CL. The ongoing debates about CIL as described in Ref. [9-12] was actually having its core as depicted in Fig. 4 in which this paper called as LWT-CL. It was too hard for a social scientist to do such work, but it is well understandable for a scientist (physicist) to identify a conservation law in nature which is acceptable like "in heaven is the same as on earth". Such thought was based on unchanging rules in both interval time and space for example stated and explained shortly in Ref. [16-22], for instance: 34 in an alien galaxy is equal to 34 on earth of Milky Way galaxy.

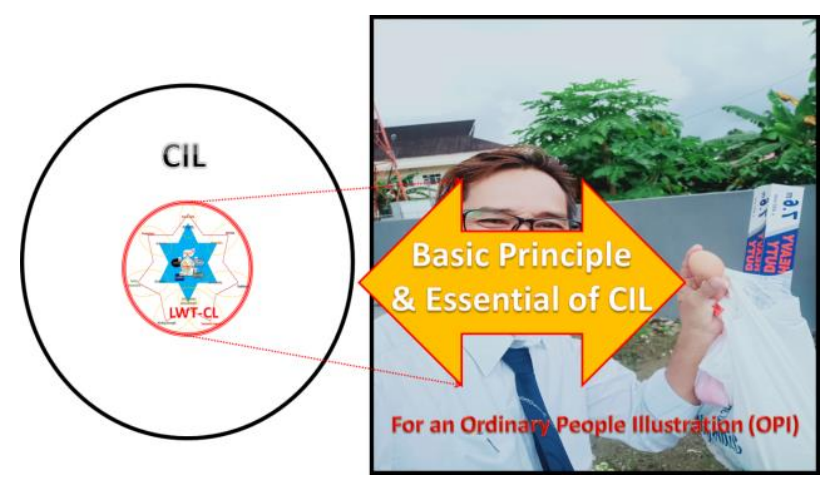

Figure 7. The thought of general picture of the relationship between CIL [10-12] and LWT-CL in this study.

\section{Conclusion}

In summary, this work based on the frontier interdisciplinary studies associated with customary law has obtained 5 significant integrated aspects of (1). History, (2). Laws, (3). Culture, (4). Science, and (5). Geoscience (or earth and space science) related obviously to the traditional development for coastal and marine protection in order to improve social-economy people life in Aru islands region. Moreover, the 5 integrated aspects were found to be in conjunction with an integrated system of 6 customary actions such as: (1). Features, (2). Characters, (3).
Connectivity, (4). Sustainable development, (5). Similarity, and (6). Attitudes. Such 6 customary actions were prominent indicators of social ordinary people life which were in direct link with local people's (1) novel idea, (2) services, (3) tradition, (4) social interactions and (5) protections. While the sustainable development was observed to be closely related to another 2 indicators of (1) economy impacts and (2) building strength. According to the intensive and careful data collection extracted directly from the answers of 50 questions of the questioner in the 2 different villages of Wokam and Karang Guli, the above mentioned findings suggest that customary laws practiced traditionally in Aru islands region were very fruitful to enhance the local people income for sustaining their traditional coastal and marine life particularly on the harvest of lobsters and sea cucumbers. Such interesting research discovery may be useful and widely applicable to many different fields of study in science, engineering and medical practice as well as theology and special suggestions to improve the knowledge and understanding of the core source of customary law.

\section{Acknowledgement}

The research works of Martinus J. Saptenno, Sostones Sisinaru, Edwin Ubwarin, and Hendry Izaac Elim were under the support of Pattimura university research grant in the interval time from year 2018 to year 2019.

\section{Conflict of Interest}

All the interdisciplinary authors ranging from law, agriculture and physics declare that their collaborative works have no conflict of purposes both financial and inventing results. 


\section{References and Notes}

[1]. W. Lawrence Neuman, Social Research Methods: Qualitative and Quantitative Approaches, Pearson Education Limited, Seventh Edition, Edinburgh Gate, Harlow Essex, England, pp. 3-599 (2014).

[2]. A. M. Novikov, and D.A. Novikov, Research Methodology: From Philosophy of Science to Research, CRC Press, Taylor \& Francis Group, Broken Sound Parkway NW, pp. 5-130 (2013).

[3]. Adil E. Shamoo and David B. Resnik, Responsible Conduct of Research, third edition, oxford university press, UK, pp. 4-359 (2015).

[4]. W. Paul Vogt, Elaine R. Vogt, Dianne C. Gardner, and Lynne M. Haeffele, Selecting the Right Analyses for your Data: Quantitative, Qualitative, and Mixed Methods, THE GUILFORD PRESS, New York London, pp. 6-522 (2014).

[5]. AMANDA PERREAU-SAUSSINE And JAMES BERNARD MURPHY (Editors), THE NATURE OF CUSTOMARY LAW: legal, Historical and Philosophical perspectives, Cambridge university press, pp. 9- 350 (2007).

[6]. H.I. Elim, International Proceeding, FORKOM-FKIP Indonesia, 13-14 Nov. 2015 (As Plenary Speaker from 4 of them), "Building Science and Technology through The Building of Human Integrity", FKIP, UNPATTI and the national meeting of all FKIP 30 deans in the whole Indonesia, the international proceeding on pp. 27-36 (2015). ISBN: 978-602-73668-0-0

[7]. Holy Bible (e-Sword version), for example in Acts 4:11 Note: "This $\mathrm{G} 3778$ is $\mathrm{G} 2076$ the $\mathrm{G} 3588$ stone ${ }^{\mathrm{G} 3037}$ which was set at nought ${ }^{\mathrm{G} 1848}$ of $\mathrm{G5259}$ you $\mathrm{G} 5216$ builders, $\mathrm{G} 3618$ which is become $^{\mathrm{G} 1096}$ the $^{(\mathrm{G} 1519)}$ head $^{\mathrm{G} 2776}$ of the corner. $\mathrm{G} 1137$ ".

[8]. A. Goswami, Quantum mechanics, Wm.C. Brown Publishers, USA, pp. 193-194 (1992).

[9]. A.C. Diala, The concept of living customary law: a critique, $J$. Legal Plur. \& Unoff. Law 49(2), pp. 143-165 (2017).

[10]. L. Blutman, Conceptual Confusion and Methodological Deficiencies: Some Ways that Theories on Customary International Law Fail, Euro. J. Inter. Law 25(2), pp. 529-552 (2014)
[11]. A.T. Guzman and J. Hsiang, Some Ways that Theories on Customary International Law Fail: A Reply to László Blutman, Euro. J. Inter. Law 25(2), pp. 553-559 (2014).

[12]. S. Talmon, Determining Customary International Law: The ICJ's Methodology between Induction, Deduction and Assertion, Euro. J. Inter. Law 26(2), pp. 417-443 (2015).

[13]. D.B. Napoh, RECOGNITION OF THE CUSTOMARY LAND LAW IN THE CONSTITUTION OF INDONESIA AND MALAYSIA, Brawijaya Law J.: Journal of Legal Studies 2(2), pp. 1-109 (2015). DOI: http://dx.doi.org/10.21776/ub.blj.2015.002.02.01

[14]. D. Sukarti, Customary Law of Inheritance and Migration: Adoption of the Old Regime or Adaptation to the New One?, AHKAM 17 (2), pp. 301-320 (2017).

[15]. Sukarti, Dewi. "Undang-undang Simbur Cahaya: Potret Politik Hukum Kolonial Belanda pada Masyarakat Palembang, dalam Ahkam: Jurnal Syari'ah-Hukum dan Pranata Sosial, no. $16 / \mathrm{VII} / 2005$.

[16]. H.I. Elim, Nonlinear Optics and The Frontier of Nanoscience and Nanotechnology, Pattimura University Press, pp. 1-144 (2018). ISBN: 987-602-61906-9-7.

[17]. H.I. Elim, METODE FISIKA EKSPERIMEN: PELENGKAP TEORI FISIKA: "To be Perfect like The 1 Who Created Our Incredible Universe", Pattimura university press, Indonesia, pp. 1-155 (2018). ISBN : 978-602-5943-05-8

[18]. H.I. Elim, Scientific Breakthrough Based on Natural Creation: "1 Diamond with 7 Eyes", COJ Reviews and Research Vol. 1(1), pp.1-4 (2018).

[19]. H.I. Elim, Multitasking Herbal Nanomedicine: A Frontier Report, Nanoscale Reports Vol. 2(1), pp. 22-30 (2019).

[20]. H.I. Elim, Theory, Implementation and the Nature of Truth (TIN) in Nanoscience, Nanotechnology, and Nanomedicine ( NNN): From the Beginning of Universe to nm Scale Behavior, Kenkyu Journal of Nanotechnology \& Nanoscience 5:33-36 (2019)

[21]. H.I. Elim, The First 1000 Atoms in Healing Process: From Nanotechnology to Nanomedicine, International Journal of Health Medicine and Current Research Vol. 3, Issue 04, pp.1044-1046, December, 2018. DOI: 10.22301/IJHMCR.2528-3189.1044 
Customary Law Associated with Five Integrated Aspects in Developing Traditional Coastal and Marine Protections for Impraving Sacial People Life and Natural Products in Aru Islands Region of Maluku Province, Indonesia

[22]. H.I. Elim (Elim Heaven), A.L. Mapanawang, and M.V. Reddy, A Creative Proposal to Improve Woman and Child Health: from the Knowledge of Physical Nanoscience to Nanotechnology Implementation and Products, CPQ Women and Child Health, 1(6), 01-11 (2019).

\section{Corresponding Authors CV:}

*Prof.Dr. M.J. Saptenno, S.H, M.Hum is a senior professor in law faculty of Pattimura university as well as rector of the university. He has published many books and articles in various publishing companies. Prof. Nus (his nick name) has also contributed many invited talks in a lot of different conferences and seminars. He has currently established Pattimura university as a BLU university (half private university) starting from year 2019.

\#Assoc. Prof. H.I. Elim, Ph.D is a talented young scientist at Pattimura university who has pioneered the first nanotechnology research center and innovative creation in the eastern part of Indonesia at Pattimura university since 24 th April 2015 with various scientific contributions such as over 18 international publications in the last 5 years and more than 3 international invited talks in his field in many different countries such as USA, Singapore and Indonesia. Dr. Elim is now the 3rd best physicist in Indonesia with h index of 23 and citations of 2300 based on Scopus, Wos dan Sinta data, respectively.

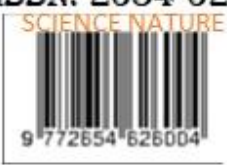




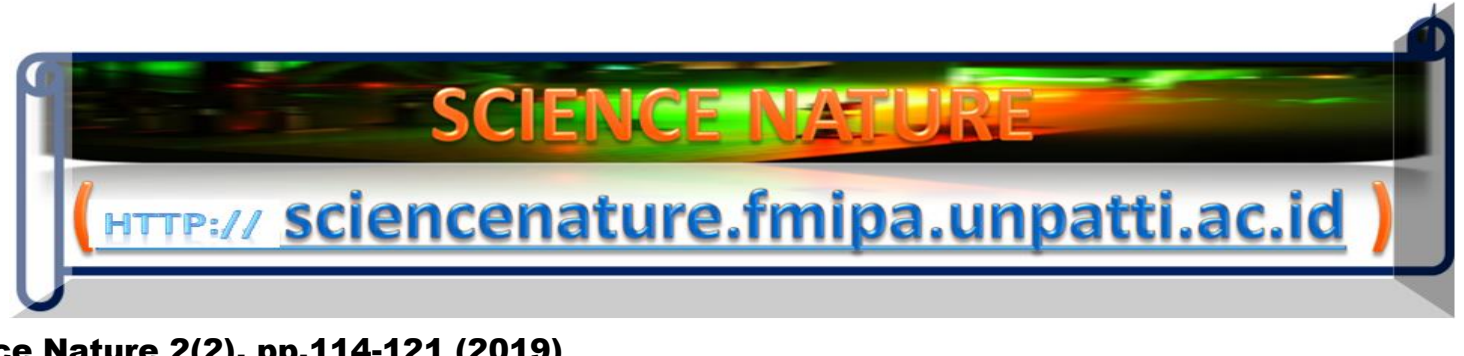

Science Nature 2(2), pp.114-121 (2019)

e-ISSN: 2654-6264

DOI: https://doi.org/10.30598/SNVol2Iss2pp114-121y2019

\title{
A Frontier 2D Nanobattery: "Improving Challenges (Hotumese) and Development"
}

\author{
Hendry Izaac Elim, ${ }^{1-6,{ }^{*}}$ M.V. Reddy, ${ }^{7,(6)}$ and Rajan Jose ${ }^{8}$ \\ ${ }^{1}$ Nanomaterials for Photonics Nanotechnology Laboratory (N4PN Lab.), Department of \\ Physics, Faculty of Mathematics and Natural Sciences, Pattimura University, \\ Jl. Ir. M. Putuhena, Poka, Ambon, Indonesia 97233 \\ ${ }^{2}$ Nanotechnology Research Center and Innovative Creation (PPNRI-LEMLIT), Research \\ Center of Pattimura University, Pattimura University Campus, \\ Jl. Mr. CHR. Soplanit, Rumah Tiga, Ambon, Indonesia 97234 \\ ${ }^{3}$ Multidisciplinary Research Center of Excellence (MrCE), UNPATTI, \\ Jl. Chr. Soplanit, RumahTiga, Ambon, Indonesia 97234 \\ ${ }^{4}$ Theoretical Physics Laboratory, Physics department, Pattimurauniversity, Ambon, Indonesia 97233 \\ ${ }^{5}$ Development and Innovative Center (PPI) of Pattimura University, Indonesia \\ ${ }^{6}$ Specific Laboratory of Electronics and Instrumentation (ELINS Lab.), \\ Physics Department, Pattimura University, Ambon, Maluku, Indonesia 97233 \\ ${ }^{7}$ Centre of Excellence in Transportation Electrification and Energy Storage (CETEES), Hydro-Québec, 1806, \\ Lionel-Boulet blvd., Varennes, Qc, J3X 1S1, Canada \\ ${ }^{8}$ Nanostructured Renewable Energy Materials Laboratory, Faculty of Industrial Sciences \& Technology, \\ Universiti Malaysia Pahang, 26300, Kuantan, Malaysia
}

Received : June 1, 2019

Revised : June 7, 2019

Published : June 12, 2019

Copyright @ All rights are reserved by H.I. Elim, M.V. Reddy, and Rajan Jose.

Corresponding author: Email: " ${ }^{*}$ hendry.elim@ @staff.unpatti.ac.id (HIE); ${ }^{*}$ MogalahalliVenkatesh.VenkatashamyReddy@ireq.ca (MVR) 
Abstract

A brief conceptual challenges improvement (hotumese) and development of nanobattery is explained in a wide insight of intuition idea and technology planning for a better future human kind life particularly in their needs of mobile effective energy.

Keywords: Nanobattery, Nanoelectrolyte, Nanoelectrode, Hotumese, Development.

\section{CONCEPTUAL}

Nanobattery with the size and its fantastic structures of about 1000 times smaller than the diameter of human being hair is very attractive due to its large energy storage in $\mathrm{nm}$ size as well as stable thermal and mechanical properties because of its inner confinement effects [1-3]. A brief history of nanobattery with its $18^{\text {th }}$ and $19^{\text {th }}$ century inventors is depicted in Fig. 0. Moreover, the idea of building better battery up to nanometer size and structure has been in very intensive efforts during the last two decades [4-11]. Beside such incredible works, many collaborative researches from interdisciplinary talented scientists have shown so many different aspects in the improvement and development focused on commercial lithium ion battery (LIB) [12-55]. Such scientific findings contributed in at least 3 advantages points of the LIB as follows [4-55]: (1). High energy density, (2). Design flexibility, and (3). Ease of handling compared to other conventional batteries. While another 2 disadvantages of a novel storage device using worldwide LIB technology are (1). The limitation of suitable electrodes and electrolytes, and (2). Complicated tasks in controlling the electrode-electrolyte interfaces. On the other hand, the next sophisticated nanobatteries need an on-target improvement and development particularly in all creative solid-state assembly

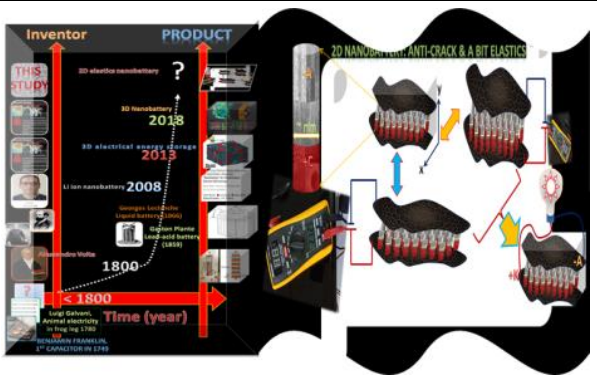

contributed and supported by both highly conducting and stable confinement solid electrolytes.

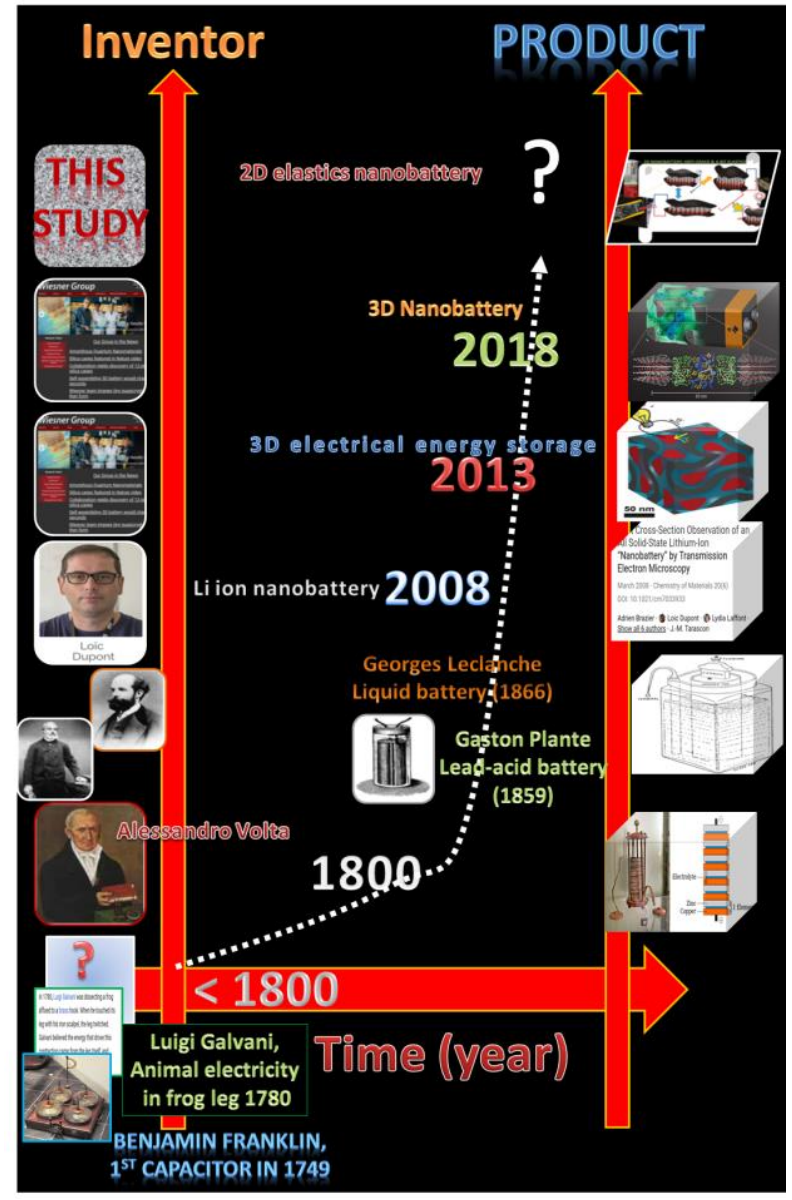

Figure 0. Brief history of nanobattery with the background of $18^{\text {th }}$ and $19^{\text {th }}$ century inventors who did various pioneer ideas and prototypes of both capacitor and battery. 
Another view of improving challenges (hotumese in Ambon, Indonesia language) in conjunction with nanotechnology strorage mobile nanobattery (SMN-B) for future energy sources is about a great hope in order to develop nano-electrode and nano-electrolite materials with excellence conductivity in a dynamics field based on gold nanoparticles [56] or gold nanorod [57], and carbon nanomaterials such as fullerene derivatives [58], carbon nanotubes (CNT) [59], and another complex nanostructure materials, for instance proposed by L. Dupont [60], and U. Weisner [61,62] with their unique physical behaviors. Nanocrystals electrolyte made by a well-known electrolyte [1-62] can solve at least the following 3 problems: (1). Large energy storage capacity, (2). Effective charge-discharge kinetics system, and (3). Cyclic instabilities which can be protected by making large surface for faradaic reaction and short distance for mass and charge diffusion.

In present paper, a dream anti-crack and elastic nanobattery system is proposed as shown in Fig. 1. The conceptual idea expanded as earlier mentioned in Ref. [63] is possible to be realized by fabricating the best nanomaterials consisted of an integrated system using nanoelectodes-electrolyte structure attached with a very thin 2D graphene like materials. However, a further hotumese and development of unique anti-crack and slightly elastic nanobattery requires excellent nanohybrid materials to proceed negative and positive nano-electrodes with precise interface with nano-electrolite grains. Currently, the best positive electrode nanomaterials so far for LIB is lithium iron phosphate (LFP) $[30-31,34]$ due to its 5 remarkable characters as follows: (1). Stable structure, (2). Less susceptible to degradation over cycles, (3). Good durability of calendar life, (4). Low preparation cost, and (5). Stability over full de-lithiation and environmental benignity. Even though LFP has good safety in use because of its stability in high temperature without the produce of oxygen, the weakness of LFP was obtained due to its low intrinsic electrical conductivity, which could be overcome by developing suitable architectures such as carbon coating [15-20]. On the other hand, a good partner of LFP to improve a better nanobattery can be lithium lanthanum titanate (LLTO) inorganic solid electrolyte that exhibits desirable lithium ion conductivities with its bulk conductivity of $10^{-3} \mathrm{~S} \mathrm{~cm}^{-1}$ and a grain boundary conductivity of $10^{-5} \mathrm{~S} \mathrm{~cm}^{-1}$ in a room temperature [22]. This value is as large as those counter parts of liquid electrolytes [24-29]. In spite of its goodness, the LLTO has thermal expansion and grain boundary problems as well as unstable against lithium metal with higher redox potential, and poor cyclability with most of the coupling electrodes $[\mathbf{2 3}, \mathbf{2 6}]$. Therefore, a dramatically hotumese and development of nanoelectrolyte must be carried out and achieved by fabricating nanocrystals electrolyte with admirable 3 important points: (1). Large energy storage capacity, (2). Exceptional charge-discharge kinetics system, and (3). Cyclic stabilities which protects nanobattery by making large surface for faradaic reaction and short distance for mass and charge diffusion. Such thought is a main part of all creative solid-state assemblies contributed and supported by both highly conducting and stable confinement solid electrolytes.

In summary, we believe that by a careful hotumese and development of anti-crack and slightly eleastic 2D nanobattery the most sophisticated future nanobattery can be attained for worldwide multitasking applications.

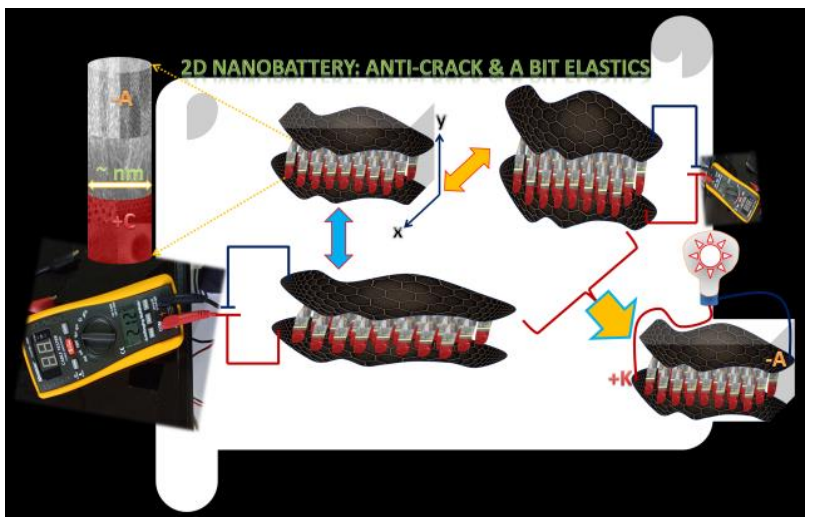

Figure 1. Illustration of conceptual future $2 \mathrm{D}$ nanobattery that has anti-crack and good elasticity with unique electrical behaviors. 


\section{Acknowledgement}

All the authors of HIE, MVR, and RJ would like to gratefully thank Indonesia Ministry of Higher Education (Ristek-Dikti) for their very competitive funding called as a world class research (WCR) granted in the interval year of 2019 to 2021 with the research project title of "Nanotechnology Strorage Mobile NanoBattery (SMN-B) for Future Energy Sources".,

\section{Conflict of Interest}

All the scientists declare that they have no any conflict in their works both financial and ideas.

\section{References}

[1]. D. Darbara, M.R. Anilkumard, V. Rajagopalanb, I. Bhattacharyac, H.I. Elim, T. Ramakrishnappaf, F.I. Ezema, R. Jose, M.V. Reddy, Studies on spinel cobaltites, $\mathrm{MCo}_{2} \mathrm{O}_{4}(\mathrm{M}=$ $\mathrm{Mn}, \mathrm{Zn}, \mathrm{Fe}, \mathrm{Ni}$ and $\mathrm{Co}$ ) and their functional properties, Ceramics International 44, pp. 4630-4639 (2018).

[2]. M.V. Reddy, G.V. Subba Rao, B.V.R. Chowdari, Metal oxides and oxysalts as anode materials for $\mathrm{Li}$ ion batteries, Chem. Rev. 113, pp. 5364-5457 (2013).

[3]. H.I. Elim, Nonlinear Optics and The Frontier of Nanoscience and Nanotechnology, Pattimura University Press, pp. 1-144 (2018). ISBN: 987-602-61906-9-7.

[4]. M. Armand, J.M. Tarascon. Building better batteries, Nat. 451(7), pp. 652-657 (2008). https://doi.org/10.1038/451652a.

[5]. A. R. Armstrong, P.G. Bruce, Synthesis of layered $\mathrm{LiMnO}_{2}$ as an electrode for rechargeable lithium batteries, Nat. 381, pp. 499-500 (1996). https://doi.org/10.1038/381499a0.

[6]. P. Poizot, S. Laruelle, S. Grugeon, L. Dupont, J.M.Tarascon, Nano-sized transition - metal oxides as negative-electrode materials for lithium-ion batteries, Nat. 407, pp 496-499 (2000). https://doi.org/10.1038/35035045.

[7]. K. P. Abhilash, P. Christopher Selvin, B. Nalini, Hui Xia, Stefan Adams, M. V. Reddy, Electrochemical analysis of the carbon-encapsulated Lithium iron phosphate nanochains and their high-temperature conductivity profiles, ACS Omega 3, pp. 6446-6455 (2018). https://doi.org/10.1021/acsomega.8b00527.
[8]. Shihan Yan, K. P. Abhilash, Lingyu Tang, Mei Yang, Yifan Ma, Qiuying Xia, Qiubo Guo, Hui Xia, Research Advances of Amorphous Metal Oxides in Electrochemical Energy Storage and Conversion, Small 15, pp. 1804371 (1-30) (2018). https://doi.org/10.1002/smll.201804371.

[9]. M. R. Palacin, Recent advances in rechargeable battery materials: a chemist's perspective, Chem. Soc. Rev. 38, pp. 2565-2575 (2009). https://doi.org/10.1039/B820555H.

[10]. H. Tang, J. Xu, Enhanced electrochemical performance of $\mathrm{LiFePO}_{4}$ coated with $\mathrm{Li}_{0.34} \mathrm{La}_{0.51} \mathrm{TiO}_{2.94}$ by rheological phase reaction method, Mater. Sci. Eng. B. 178, pp. 1503-1508 (2013). https://doi.org/10.1016/j.mseb.2013.08.014.

[11]. N. S. Choi, Z. Chen, S. A. Freunberger, X. Ji, Y.K. Sun, K. Amine, G.Yushin, L. F. Nazar, J. Cho, P.G. Bruce, Challenges Facing Lithium Batteries and Electrical Double-Layer Capacitors, Angew. Chem. Int. Ed. 51, pp. 9994-10024 (2012). https://doi.org/10.1002/anie.201201429.

[12]. M.G. Kim, J. Cho, Reversible and high-capacity nanostructured electrode materials for Li-Ion batteries, Adv. Funct. Mater. 20, pp. 1497-1514 (2009). https://doi.org/10.1002/adfm.200801095.

[13]. T. Cheisson and E.J. Schelter, Rare earth elements: Mendeleev's bane, modern marvels, Science pp. 489-493 (2019).

[14]. M.V. Reddy, C. Yu, F. Jiahuan, K.P. Loh, B.V.R. Chowdari, V. Thavasi, C.H. Sow, S.G. Mhaisalkar, S. Ramakrishna, B.V.R. Chowdari, Molten salt synthesis and energy storage studies on $\mathrm{CuCo} 2 \mathrm{O} 4$ and $\mathrm{CuO} \cdot \mathrm{Co} 3 \mathrm{O} 4, \boldsymbol{R S C}$ Adv. 2, p. 9619 (2012).

[15]. M.V. Reddy, Y. Xu, V. Rajarajan, T. Ouyang, B.V.R. Chowdari, Template free facile molten synthesis and energy storage studies on $\mathrm{MCo} 2 \mathrm{O} 4(\mathrm{M}=\mathrm{Mg}, \mathrm{Mn})$ as anode for Li-ion batteries, $\boldsymbol{A C S}$ Sustain. Chem. Eng. 3, pp. 3035-3042 (2015).

[16]. X. Gao, C.A.J. Fisher, T. Kimura, Y.H. Ikuhara, H. Moriwake, A. Kuwabara, H. Oki , T. Tojigamori, R. Huang, Lithium atom and A-site vacancy distributions in lanthanum lithium titanate, Chem. Mater. 25(9), pp. 1607-1614 (2013). https://doi.org/10.1021/cm3041357.

[17]. J.B. Goodenough, Y. Kim, Challenges for rechargeable Li batteries. Chem. Mater. 22, pp. 587-603 (2010). https://doi.org/10.1021/cm901452z.

[18]. D. Qian, B. Xu, H.M. Cho, T. Hatsukade, K. J. Carroll, Y. S. Meng, Lithium Lanthanum Titanium Oxides: A Fast Ionic Conductive Coating for Lithium-Ion Battery Cathodes, Chem. 
Mater. 24(14), pp. $2744-2751$ (2012).

https://doi.org/10.1021/cm300929r.

[19]. P. Sivaraj, K. P. Abhilash, B. Nalini, P. Balraju, Sudheer Kumar Yadav, S. Jayapandi, P. Christopher Selvin, Structure, dielectric, and temperature-dependent conductivity studies of the $\mathrm{Li}_{2} \mathrm{FeSiO}_{4} / \mathrm{C}$ nano cathode material for lithium-ion batteries, Ionics 25, pp. 2041-2056 (2019). https://doi.org/10.1007/s11581-018-2685-1.

[20]. P. Perumal, K. P Abhilash, P. Sivaraj, P.C. Selvin, Study on Mg-ion conducting solid biopolymer electrolytes based on tamarind seed polysaccharide for magnesium ion batteries, Materials Research Bulletin 118, p. 110490 (2019). https://doi.org/10.1016/j.materresbull.2019.05.015.

[21]. K.F. Hsu, S.Y. Tsay, B.J. Hwang, Synthesis and characterization of nano-sized $\mathrm{LiFePO}_{4}$ cathode materials prepared by a citric acid-based sol-gel route, J. Mater. Chem. 14, pp. 2690- 2695 (2004). https://doi.org/10.1039/B406774F.

[22]. B. Antoniassi, A.H.M. Gonzalez, S.L. Fernandes, C.F.O. Graeff, Microstructural and electrochemical study of $\mathrm{La}_{0.5} \mathrm{Li}_{0.5} \mathrm{TiO}_{3}$, Mater. Chem. Phys. 127, pp. $51-55$ (2011). https://doi.org/10.1016/i.matchemphys.2010.12.021.

[23]. M.Yang, J. Hou, Membranes in lithium ion batteries,

Membrane. 2, pp. 367-383 (2012).

https://doi.org/10.3390/membranes2030367.

[24]. J. Ibarra, A.Vareza, C. Leon, J. Santamaria, L.M.

Torres-Martinez, J. Sanz, Influence of composition on the structure and conductivity of the fast ionic conductors $\mathrm{La}_{2 / 3-x}$ $\mathrm{Li}_{3 \mathrm{x}} \mathrm{TiO}_{3}(0.03 \leq 3 x \leq 0.167)$, Solid State Ion. 134(3-4), pp. 219-228 (2000). https://doi.org/10.1016/S0167-2738(00)00761-X.

[25]. O. Bohnke, Q. N. Pham, A. Boulant, J. Emery, T. Salkus, M. Barre, $\mathrm{H}^{+} / \mathrm{Li}^{+}$exchange property of $\mathrm{Li}_{3 X} \mathrm{La}_{2 / 3-X} \mathrm{TiO}_{3}$ in water and in humid atmosphere. Solid State Ion. 188(1), pp. 144-147 (2011). https://doi.org/10.1016/j.ssi.2010.09.058.

[26]. C. W. Ban, G. M. Choi, The effect of sintering on the grain boundary conductivity of lithium lanthanum titanates, Solid State Ion. 140(3-4), pp. 285-292 (2001). https://doi.org/10.1016/S0167-2738(01)00821-9.

[27]. K.P.Abhilash, P.ChristopherSelvin, B.Nalini, K.Somasundaram, P.Sivaraj, A.Chandra Bose, Study of the temperature dependent transport properties in nanocrystalline lithium lanthanum titanate for lithium ion batteries, J. Phys. Chem.
Solids. 91, pp. 114-121 (2016),

http://dx.doi.org/10.1016/j.jpcs.2015.12.015.

[28]. K. Y. Yang, H. W. Wang, K. Z. Fung, Roles of lithium ions and $\mathrm{La} / \mathrm{Li}$-site vacancies in sinterability and total ionic conduction properties of polycrystalline $\mathrm{Li}_{3} x \mathrm{La}_{2 / 3}-x \mathrm{TiO}_{3}$ solid electrolytes $(0.21 \leq 3 x \leq 0.50)$, J. Alloys Compd. 458(1-2), pp. 415-424 (2008). https://doi.org/10.1016/j.jallcom.2007.03.130.

[29]. H.X. Geng, A. Mei, C. Dong, Y.H. Lin, C.W. Nan, Investigation of structure and electrical properties of $\mathrm{Li}_{0.5} \mathrm{La}_{0.5} \mathrm{TiO}_{3}$ ceramics via microwave sintering, J. Alloys. Compd. 481, pp. 555-558 (2009). https://doi.org/10.1016/j.jallcom.2009.03.038.

[30]. H. Matsuia, T. Nakamuraa, Y. Kobayashib, M.Tabuchic, Y. Yamada, Open-circuit voltage study on $\mathrm{LiFePO}_{4}$ olivine cathode, J. Power Sources 195, pp. 6879-6883 (2010). https://doi.org/10.1016/j.jpowsour.2010.04.072.

[31]. N. Iltchev, Y. Chen, S. Okada, J. Yamaki, $\underline{\operatorname{LiFePO}}_{4} \underline{\text { storage at }}$ room and elevated temperatures, J. Power sources 119-121, pp. 749-754 (2003). https://doi.org/10.1016/S0378-7753(03)00215-5.

[32]. K. H. Kim, Y. Iriyama, K. Yamamoto, S. Kumazaki, T.Asaka, K. Tanabe, C. A.J. Fisher, T. Hirayama, R. Murugan, Z. Ogumi, Characterization of the interface between $\mathrm{LiCoO}_{2}$ and $\mathrm{Li}_{7} \mathrm{La}_{3} \mathrm{Zr}_{2} \mathrm{O}_{12}$ in an all solid state rechargeable lithium battery. $\boldsymbol{J}$. Power sources. 196, pp. 764-767 (2011). https://doi.org/10.1016/j.jpowsour.2010.07.073.

[33]. Y. Liang, L. Ji, B. Guo, Z. Lin, Y. Yao, Y. Li, M. Alcoutlabi, Y. Qiu, X. Zhang, Preparation and electrochemical characterization of ionic-conducting lithium lanthanum titanate oxide/polyacrylonitrile submicron composite fiber-based lithium-ion battery separators, J. Power Sources. 196, pp. 436-441 (2011). https://doi.org/10.1016/j.jpowsour.2010.06.088.

[34]. M.Kopec, A.Yamanda, G. Kobayashi, S. Nishimura, Structural and magnetic properties of $\mathrm{Li}_{\mathrm{x}}\left(\mathrm{Mn}_{\mathrm{y}} \mathrm{Fe}_{1-\mathrm{y}}\right) \mathrm{PO}_{4}$ electrode materials for Li-ion batteries, J. Power sources. 189, pp. 1154-1163 (2009). https://doi.org/10.1016/j.jpowsour.2008.12.096.

[35]. C. C. Hunter, D. C. Sinclair, A. R. West, A. Hooper, A.C. impedance studies of the lithium/polymer electrolyte interface in solid-state lithium cells, J. Power Sources. 24, pp. 157-164 (1988). https://doi.org/10.1016/0378-7753(88)80099-5.

[36]. K.P.Abhilash, P.Sivaraj, P.ChristopherSelvin, B.Nalini, K.Somasundaram, Investigation on spin coated LLTO thin film nano-electrolytes for rechargeable lithium ion batteries, Ceram. 
Int. 41, pp. 13823-13829 (2015).

http://dx.doi.org/10.1016/j.ceramint.2015.08.067.

[37]. K.P. Abhilash, P. Christopher Selvin, B. Nalini, P. Nithyadharseni, B.C. Pillai, Investigations of pure and Ag doped lithium lanthanum titanate (LLTO) ceramic electrolytes for rechargeable lithium-ion batteries, Ceram. Int. 39, pp. 947-952 (2013). https://doi.org/10.1016/j.ceramint.2012.07.011.

[38]. A. Sakuda, A. Hayashi, Y. Takigawa, K. Higashi, M. Tatsumisago, Evaluation of elastic modulus of Li2S-P2S5 glassy solid electrolyte by ultrasonic sound velocity measurement and compression test. J. Ceram. Soc. Jpn. 121, pp. 946-949 (2013). https://doi.org/10.2109/jcersj2.121.946

[39]. A. Sakuda, A. Hayashi, M. Tatsumisago, Sulfide solid electrolyte with favorable mechanical property for all-solid-state lithium $\begin{array}{lllllll}\text { battery, } & \text { Sci. } & \text { Rep. } & \text { 3, } & \text { p. } & 2261 & \text { (2013). }\end{array}$ https://doi.org/10.1038/srep02261.

[40]. K. Kerman, A. Luntz, V. Viswanathan, Y.-M. Chiang and Z. Chen, Review-Practical Challenges Hindering the Development of Solid State Li Ion Batteries, J. Electrochem. $\begin{array}{llll}\text { Soc. } & \text { 164, } & \text { A1731-A1744 }\end{array}$ https://doi.org/10.1149/2.1571707jes.

[41]. Y.Q. Cheng, Z.H. Bi, A. Huq, M. Feygenson, C.A. Bridges, M.P. Paranthaman, B.G. Sumpter, An integrated approach for structural characterization of complex solid state electrolytes: the case of lithium lanthanum titanate, J. Mat. Chem. A. 2, pp. 2418-2426 (2014). https://doi.org/10.1039/C3TA14433J.

[42]. Zhao-Rong Chang, Hao-Jie Lv, Hong-Wei Tang, Hua-Ji Li, Xiao-Zi Yuan, Hajiang Wang, Synthesis and characterization of high-density $\mathrm{LiFePO}_{4} / \mathrm{C}$ composites as cathode materials for lithium-ion batteries, Electrochim. Acta. 54, pp. 4595-4599 (2009). https://doi.org/10.1016/j.electacta.2009.03.063.

[43]. Yan Cui, Xiaoli Zhao, Ruisong Guo, Enhanced electrochemical properties of $\mathrm{LiFePO}_{4}$ cathode material by $\mathrm{CuO}$ and carbon co-coating, J. Alloys Compd. 490, pp. 236-240 (2010). https://doi.org/10.1016/j.jallcom.2009.09.165.

[44]. P. Jasinski, V. Petrovsky, T. Suzuki, H. U. Anderson, Impedance Studies of Diffusion Phenomena and Ionic and Electronic Conductivity of Cerium Oxide. J. Electrochem. Soc. 152, pp. J27-J32 (2005). https://doi.org/10.1149/1.1861174.

[45]. D.C. Sinclair, Characterization of Electro-materials using ac Impedance Spectroscopy, Bol. Soc. Esp. Ceram. Vidrio 34 (2), pp. 55-65 (1995). boletines.secv.es/upload/199534055.pdf
[46]. I-Wei Chen, Mobility control of ceramic grain boundaries and interfaces, Mater Sci. Eng. A. 166, pp. 51-58 (1993). https://doi.org/10.1016/0921-5093(93)90309-3.

[47]. J.E. Weston, B. C. H. Steele, Effects of inert fillers on the mechanical and electrochemical properties of lithium salt-poly(ethylene oxide) polymer electrolytes. Solid State Ion. 7, pp. 75-79 (1982)

https://doi.org/10.1016/0167-2738(82)90072-8.

[48]. X. Qian, N. Gu, Z. Cheng, X. Yang, E. Wang, S. Song, Impedance study of $(\mathrm{PEO})_{10} \mathrm{LiClO}_{4}-\mathrm{Al}_{2} \mathrm{O}_{3}$ composite polymer electrolyte with blocking electrodes, Electrochim. Acta. 46, pp. 1829-1836 (2001). https://doi.org/10.1016/S0013-4686(00)00723-4.

[49]. J.T.S. Irvine, D.C. Sinclair, A.R.West, Electroceramics : Characterization by Impedance Spectroscopy. Adv. Mater. 2, pp. 132-138 (1990). https://doi.org/10.1002/adma.19900020304.

[50]. E. Barsoukov, J.R.Macdonald, Impedance Spectroscopy: Theory, Experiment, and Applications. $2^{\text {nd }}$ Edition. Hoboken, New Jersey. John Wiley \& Sons; pp 1-616 (2005).

[51]. M. Ciureanu, H. Wang, Electrochemical Impedance Study of Electrode-Membrane Assemblies in PEM Fuel Cells: I. Electro-oxidation of $\mathrm{H}_{2}$ and $\mathrm{H}_{2} / \mathrm{CO}$ Mixtures on Pt-Based Gas-Diffusion Electrodes, J. Electrochem. Soc. 146, 4031-4040 (1999). https://doi.org/10.1149/1.1392588.

[52]. D. Fauteux, Formation of a passivating film at the lithium-PEO-LiCF${ }_{3} \mathrm{SO}_{3}$ interface. Solid State Ion. 17, pp. 133-138 (1985). https://doi.org/10.1016/0167-2738(85)90061-X.

[53]. J.I. Goldstein, D.E. Newbury, D.C. Joy, C.E. Lyman, P. Echlin, E. Lifshin, L. Sawyer, J.R. Michel， Scanning Electron Microscopy and X-ray Microanalysis. $3^{\text {rd }}$ Edition. New York. Springer; pp 491-451 (2003).

[54]. M. Keddam, C.Kuntz, H.Takenouti, D.Schuster, D.Zuili, Exfoliation corrosion of alumininium alloys examined by electrode impedance, Electrochim Acta. 42, pp. $87-97$ (1997). https://doi.org/10.1016/0013-4686(96)00170-3. 
[55]. J.B. Goodenough, Y. Kim, Challenges for Rechargeable Li Batteries, Chem. Mater. 22(3), pp. 587-603 (2010). https://doi.org/10.1021/cm901452z.

[56]. Boon-Kin Pong, Hendry I. Elim, Jian-Xiong Chong, Wei Ji, Bernhardt L. Trout and Jim-Yang Lee, New Insights on Nanoparticle Growth Mechanism in Citrate-Reduction of Gold(III) Salt: Formation of Au Nanowire Intermediate and its Nonlinear Optical Properties, J. Phys. Chem. C 111, 6281 (2007).

[57]. Hendry I. Elim, Wei Ji, Mohan Singh Dhoni, N. Venkatram, Jian Yang, and Jim Yang Lee, Aspect-ratio Dependence of Optical Nonlinearities on Resonance with Longitudinal Surface Plasmon in $\mathrm{Au}$ Nanorods: Unique Character versus Common Behavior, Science Nature 1(1), pp. 1-7 (2018).

[58]. H.I. Elim and L.Y. Chiang, Nanochip Medicine: Physical Chemistry Engineering, Science Nature 2(1), pp. 86-89 (2019).

[59]. H.I. Elim, Y.W. Zhu, and C.H. Sow, Length Dependence of Ultrafast Optical Nonlinear in Vertically Aligned Multiwalled Carbon Nanotube Films, J. Phys. Chem. C 120(31), 17733-17738 (2016).

[60]. A. Brazier, L. Dupont, L. Laffont, et al., First cross-section observation of an all solid-state lithium-ion "nanobattery" by transmission electron microscopy, Chem. Mater. 20(6), (2008).
[61]. A. Maurel, M. Courty, B. Fleutot, H. Tortajada, K. Prashantha, M. Armand, S. Grugeon, S. Panier, and L. Dupont, Highly loaded graphite-polylactic acid composite-based filaments for lithium-ion battery three dimensional printing, Chem. Mater. 30(21), pp. 7484-7493 (2018).

[62]. J.G. Werner, G.G. Rodriguez-Calero, H.D. Abruna, and U. Weisner, Block copolymer derived 3-D interpenetrating multifunctional gyroidal nanohybrids for electrical energy storage, Energy \& Env. Sci. 11, pp. 1261-1270 (2018).

[63]. H.I. Elim, A.L. Mapanawang and M.V. Reddy, A Creative Proposal to Improve Woman and Child Health: from the Knowledge of Physical Nanoscience to Nanotechnology Implementation and Products, CPQ Women and Child Health 1(6), pp. 01-11, (2019).

\section{Corresponding Authors CV:}

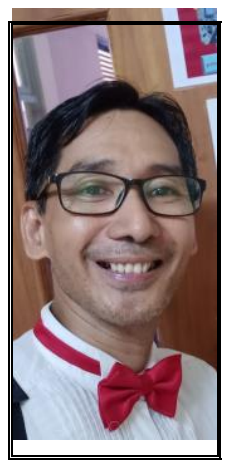

${ }^{*}$ Hendry Izaac Elim, Ph.D (Assoc.Prof.) is the $3^{\text {rd }}$ rank young Indonesia physicist with h index of $\sim 23$ based on Scopus/ Web of Science (WoS) and citations over 2200 from his excellent $\sim 75$ international publications in many different fields of physics including nanoscience, nanotechnology and nanomedicine, respectively. 


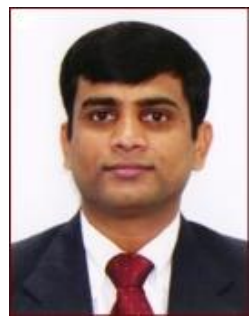

${ }^{(6)}$ Dr. M.V. Reddy is a prominent Senior Scientist in Centre of Excellence in Transportation Electrification and Energy Storage (CETEES), Hydro-Québec, 1806, Lionel-Boulet blvd., Varennes, Qc, J3X 1S1, Canada. He is number 1 Asian scientist in the field of molten salt synthesis prior to his move to Hydro-Québec based on his $\mathrm{H}$ index over 50 and more than 150 admirable high quality publications in the field as well as citation > 10,000 according to google scholar.

ORCID of M. V. R: 0000-0002-6979-5345

E-ISSN: 2654-6264

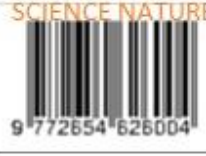




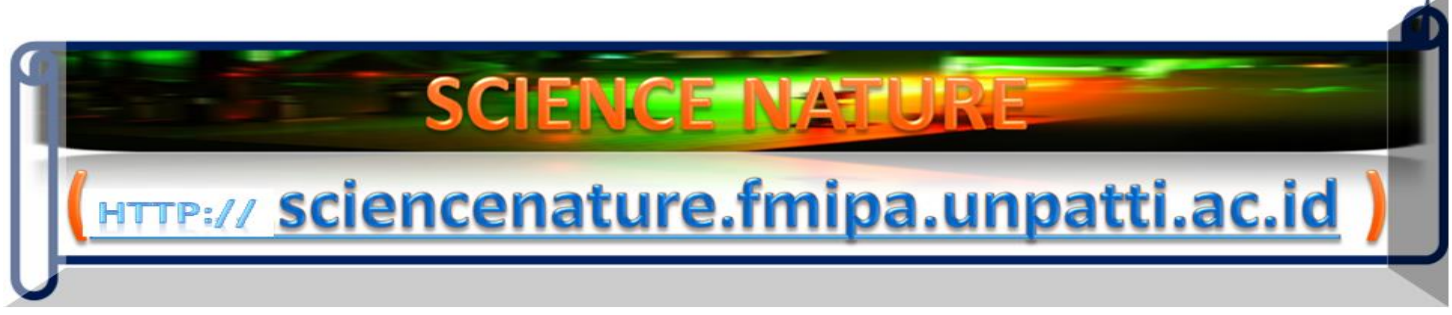

Science Nature 2(2), pp.122-127 (2019)

e-ISSN: 2654-6264

DOI: https://doi.org/10.30598/SNVol2Iss2pp114-127y2019

\title{
The Observation of Fast, Long Term, and Stable Performance of
}

\section{Toxic Absorption in Herbal Blessing Product Based on \\ Galoba Maluku (Zingiberaceae Fruits)}

\author{
Ido F. Seay ${ }^{1,2}$ and Hendry Izaac Elim ${ }^{1-6, \#}$ \\ ${ }^{1}$ Nanomaterials for Photonics Nanotechnology Laboratory (N4PN Lab.), Department of \\ Physics, Faculty of Mathematics and Natural Sciences, Pattimura University, \\ Jl. Ir. M. Putuhena, Poka, Ambon, Indonesia 97233 \\ ${ }^{2}$ Nanotechnology Research Center and Innovative Creation (PPNRI-LEMLIT), Research \\ Center of Pattimura University, Pattimura University Campus, \\ Jl. Mr. CHR. Soplanit, Rumah Tiga, Ambon, Indonesia 97234 \\ ${ }^{3}$ Multidisciplinary Research Center of Excellence (MrCE), UNPATTI, \\ Jl. Chr. Soplanit, RumahTiga, Ambon, Indonesia 97234 \\ ${ }^{4}$ Theoretical Physics Laboratory, Physics department, Pattimurauniversity, Ambon, Indonesia 97233 \\ ${ }^{5}$ Development and Innovative Center (PPI) of Pattimura University, Indonesia \\ ${ }^{6}$ Specific Laboratory of Electronics and Instrumentation (ELINS Lab.), \\ Physics Department, Pattimura University, Ambon, Maluku, Indonesia 97233
}

Received : March 29, 2019

Revised : June 12, 2019

Published : June 13, 2019

Copyright @ All rights are reserved by I.F. Seay and H.I. Elim.

Corresponding author: Email: "hendry.elim@staff.unpatti.ac.id; hendryelim@gmail.com 
The Dbservation of Fast, Long Term, and Stable Performance of Toxic Absorption in Herbal Blessing Product Based on Galoba Maluku (Zingiberaceae Fruits)

\section{Abstract}

The search for the best herbal medicine products for multitasking healing system associated with Galoba (Maluku language) or Golobe (North Maluku language) or zingiberaceae fruits are presented with a very systematic explanation after an intensive research in the last 3 years ( 2016-2019) vary from its antioxidant content of flavonoid, chemical bonding organization, HIV virus medicine test, and toxic inhibition status. We obtained that the best herbal medicine produced in this paper called as Herbal Blessing products preparing with different system of Love herbal made by STIKES Halmahera, North Maliuku, Indonesia can provide fast, long term, and stable performance of toxic absorption. Such fast toxic response is an instantaneous process with no longer than 1 minute as well as a stable toxic binding for up to 4 months and 10 days so far. The obvious observation indicated few interesting physical chemistry processes during toxic absorption such as the nitrogen gas released during the sample preparation of Herbal Blessing, and the oxygen vanished in different sample processes of the same source of Murnaten Amomum sp. observed in a protected bottle consisted of the sample interaction with toxic in water. These amazing findings suggest that Herbal Blessing products are very promising for future multitasking healing system for human excellent health.

Keywords: Galobal Golobel Zingeberaceae fruit, Love Herbal, Herbal Blessings, Multitasking Healing.

\section{LETTERS}

The incredible thing of herbal medicine [1-8] is on its excellence healing system [9-17] which is quite different from a normal pharmaceutical drug with the excellence background of synthetic chemistry. A concept

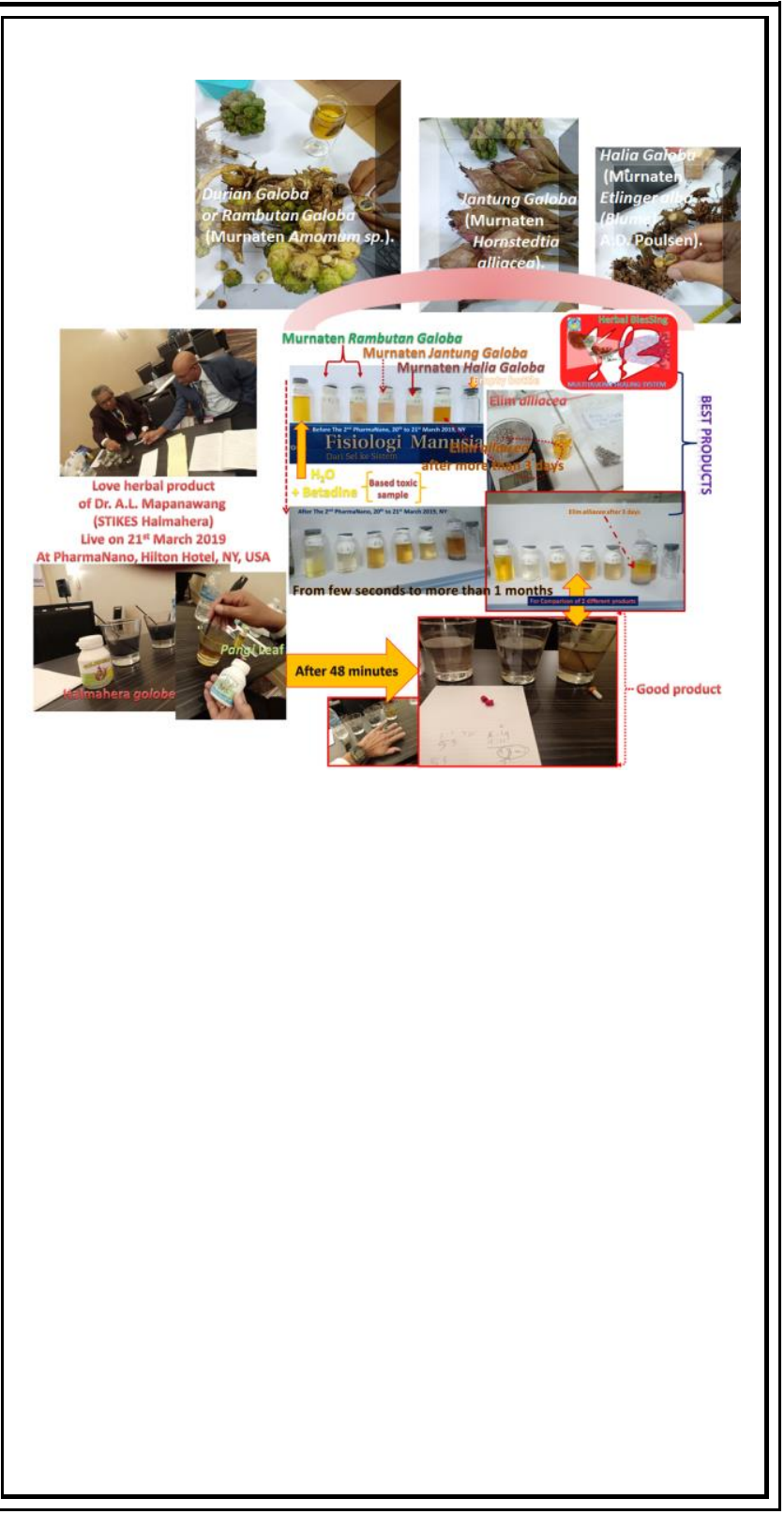

of self-healing mechanism in applied physics of nanoscience, nanotechnology and nanomedicine as described in Fig. 0 with 4 important points of (1). nanohybrid composites, (2). Emerging Bio-physics compositions, (3). Surface interactions, and (4). Wisdom density and its geometry is widely and originally found in organic natural materials such as in 
The Observation of Fast, Long Term, and Stable Performance of Toxic Absorption in Herbal Blessing Product Based on Galaba Maluku (Zingiberaceae Fruits)

fruits, roots, leaves, stems, and parts of animal's body as well as products of animal self-product, for instance in a super-elastic string of spider web. Furthermore, recently various collaborative scientists have produced many types of products with both multitasking healing system theory $[\mathbf{1 1}, \mathbf{1 2}]$ and its experimental observation, for example in herbal medicine based on Galoba / Golobe (zingiberaceae) fruits [4].

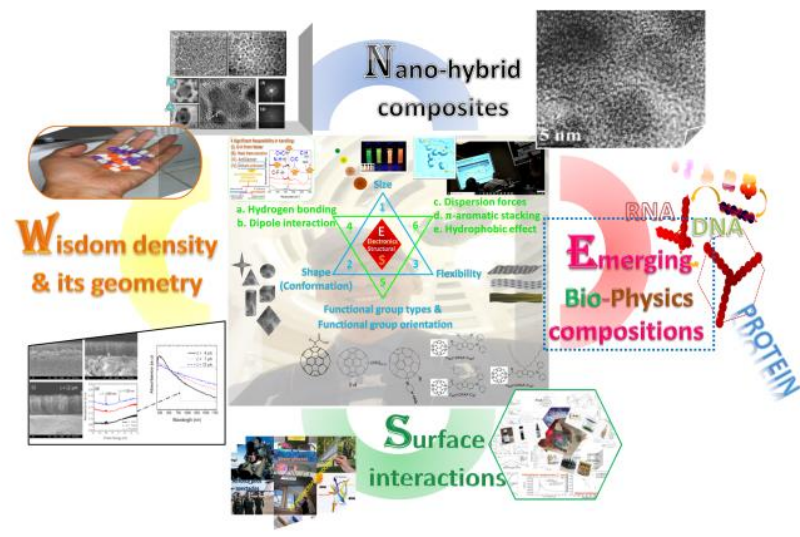

Figure 0. Self-healing mechanism in universe based on knowledge source and understanding of a collaboration among two to three atoms or molecules or cells or nanomaterials or compositions in microscopic applied physics.

In order to test the best products of herbal medicine in conjunction with the whole Galoba in Maluku and Golobe in North of Maluku fabricated before by A.L. Mapanawang, et al., STIKES Halmahera called as Love herbal [13] with its physical behaviors under collaboration with Elim of Pattimura university [14-17], ones investigated the best area in Maluku in which such interesting fruits are being grown with healthy nature and environment. We found Murnaten village in the west part of Seram island, the largest island in Maluku province as a very good area of such Galoba samples. There were 3 best types for Herbal Blessing products of the fruits identified as: (1). Durian Galoba (Murnaten Amomum sp.) called as Murnaten Ramburan Galoba, (2). Jantung Galoba (Murnaten Hornstedtia alliacea), (3). Halia Galoba (Murnaten Etlinger alba (Blume) A.D. Poulsen). Figure 1 shows the first observation of nitrogen gases detected using infrared thermometer during the fabrication of Herbal Blessing products based on Murnaten Amomum sp. fruits at Pattimura university, Ambon, Indonesia. According to the measurement of the hotplate temperature $\left(\boldsymbol{T}_{\boldsymbol{H} \boldsymbol{P}}\right)$, and the on target medicine preparation inside hotplate, the medicine can decrease the input temperature up to $50 \%$ or from measured $~ 160$ ${ }^{0} \mathrm{C}$ to be $\sim 83{ }^{0} \mathrm{C}$ in the medicine. This means that the gases have carried out half of the thermal heating out of the medicine.

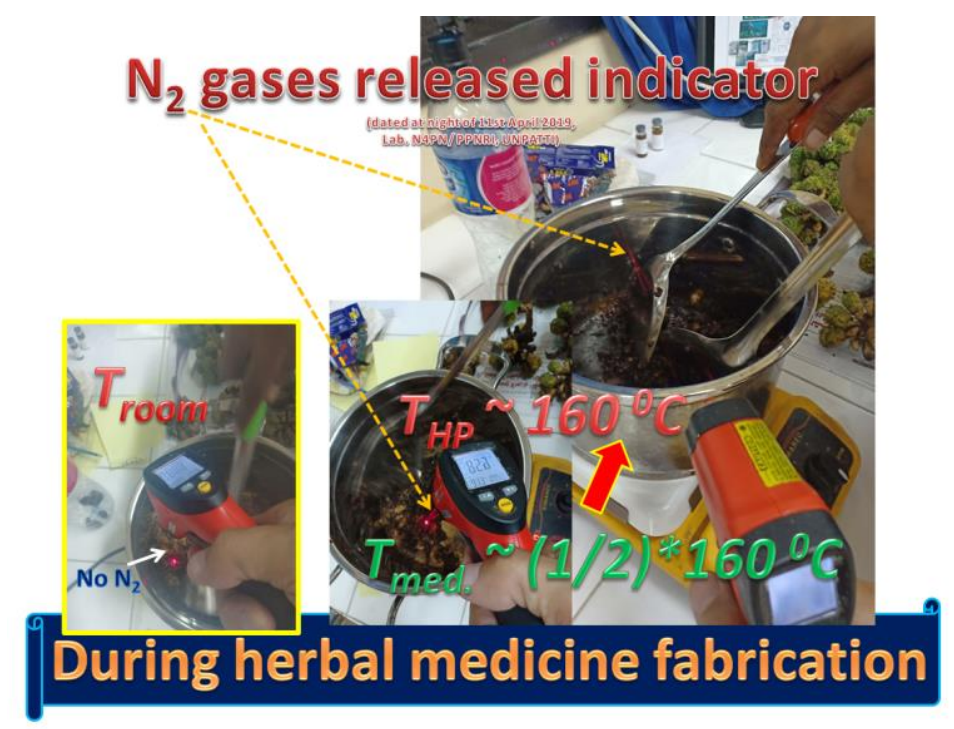

Figure 1. The observation of nitrogen gases during the fabrication of Herbal Blessing products based on Maluku zingiberaceae fruits at Pattimura university, Ambon, Indonesia. $\boldsymbol{T}_{\boldsymbol{H P}}$ is the hot plate temperature measured using infrared thermometer. While $\boldsymbol{T}_{\text {med. }}$ is the direct measurement of as fabricated Herbal Blessing product. The flow of temperature from hotplate to direct contact of the medicine was about half of the inserted temperature.

Figure 2 shows the observation of fast, long term, and stable performance of toxic absorption in Herbal Blessing Products (the logo depicted in the inset with red color) based on 4 different kinds Galoba Maluku (zingiberaceae fruits) [3] or Golobe North Maluku [13-17]. The 3 of their genus investigated in this work were collected in Murnaten, west part of Seram island consisted of: (1). Durian Galoba (Murnaten amomum 
The Observation of Fast, Long Term, and Stable Performance of Toxic Absorption in Herbal Blessing Product Based on Galoba Maluku (Zingiberaceae Fruits)

sp.) called as Murnaten Ramburan Galoba, (2). Jantung Galoba (Murnaten hornstedtia alliacea), (3). Halia Galoba (Murnaten Etlinger alba (Blume) A.D. Poulsen). The two bottles on the right were Herbal Blessing products from Murnaten Amomum sp. with two different sample preparations with their interactions with betadine toxic (a common wound medicine in Indonesia with dark yellow color) in water, respectively. We obtained that because of the different prepared medicines, the output toxic response and ability was also different indicated with the different colors of absorption process as shown in Fig. 2. Therefore, there was sample preparation dependence on the quality of herbal medicine. On the other sides, the two left bottles were containing Herbal Blessing products made by Murnaten Hornstedtia alliacea and Murnaten Etlinger alba (Blume) A.D. Poulsen. All the observed healing mechanism of the Herbal Blessing products have been identified in the last $\mathbf{4}$ months plus 10 days starting from as fabricated samples on $13^{\text {rd }}$ February 2019. It is still stable up today due to unchanging color of the solutions. These findings are much better than that observed in Elim alliacea herbal medicine in Ref. [3], which was only 3 days toxic absorption and then the $4^{\text {th }}$ day and so forth the toxic came out.

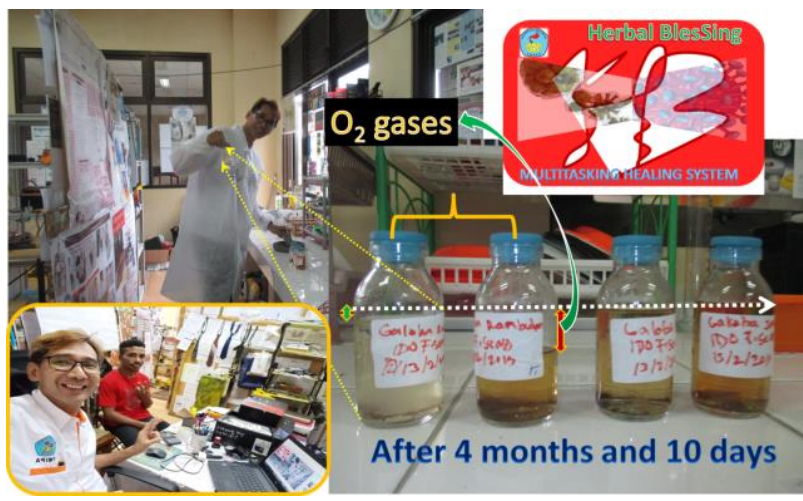

Figure 2. The observation of fast, long term, and stable performance of toxic absorption in Herbal Blessing Products (the logo depicted in the inset with red color) based on 4 different kinds [3,14-17] of Galoba Maluku (zingiberaceae fruits) collected both in Layeni village [3], and in Murnaten, west part of Seram island, respectively.
After all different sample preparations as depicted in Fig. 3 with its comparison with former Love herbal of STIKES Halmahera product as demonstrated during PharmaNano in New York on $20^{\text {th }}$ to $21^{\text {st }}$ March 2019, ones find out that the medicine response in absorbing toxic (betadine) of Love herbal was the slowest or about 48 minutes in order to reduce all the toxic as indicated in a clear water-toxic solution. While according to experimental observation in Herbal Blessing products from 13rd February 2019 up to present, the response time to absorb all the betadine toxic in water is just in a minute or few minutes depending on the genus of Galobe based herbal medicine. Furthermore, it is interesting to point out that such absorption was very stable. On the other words, the toxic cannot be escaped from the medicine for more than 4 months. The quality of water after such long term absorption is also much more clearly than that in Love herbal. That was the reason why ones distinguish the two different herbal medicine products as the best (Herbal Blessing) and good (Herbal love) products as marked inside Fig. 3.

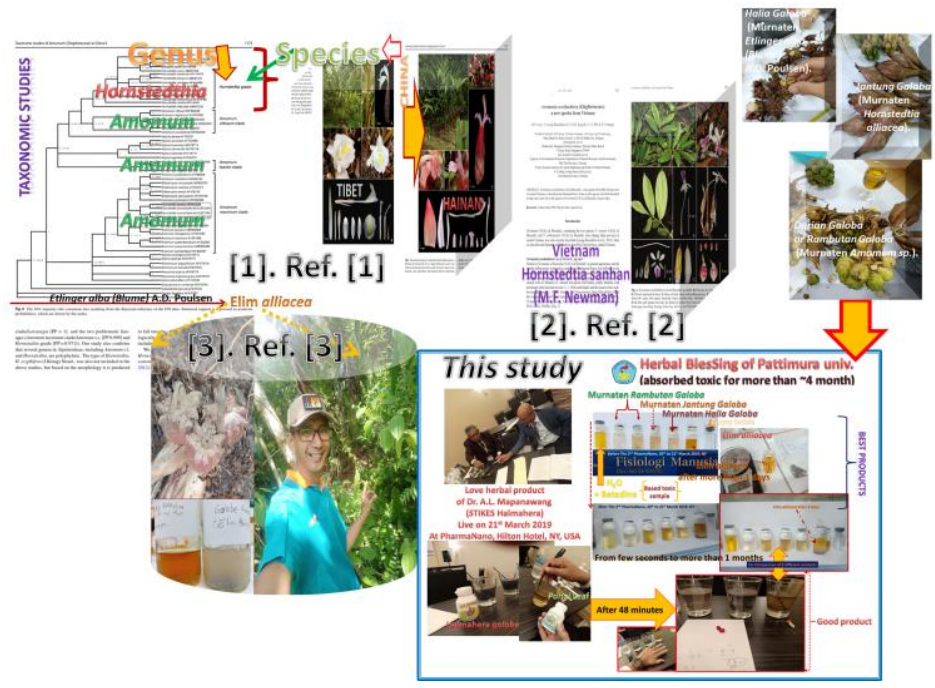

Figure 3. The best (Herbal Blessing products) versus a good (Love Herbal) herbal medicines based on at least 4 identified genus of Galoba (zingiberaceae fruits) worldwide: (1) Hornstedtia, (2) Amomum, (3) Etlinger alba (blume), and (4) $\operatorname{Elim}[\mathbf{3 , 4 , 1 3 - 1 7 ]}$ 
The Observation of Fast, Long Term, and Stable Performance of Toxic Absorption in Herbal Blessing Product Based on Galoba Maluku (Zingiberaceae Fruits)

The remark of this work is that the invention of Herbal Blessing products reported in this paper will make worldwide impacts on multitasking healing system to improve human health or at least keep daily healthy life due to their fast, long term, and stable performance of toxic absorption, respectively. Such Herbal Blessing is like a molecular battery for human body activities as illustrated in Ref.[8,18].

\section{Acknowledgement}

HIE is grateful to thank Indonesia Ministry of Higher Education (Ristek-Dikti) from this year of 2019 to 2021 for providing a very competitive research grant called as a world class research (WCR) fund entitled as "Nanotechnology Strorage Mobile NanoBattery (SMN-B) for Future Energy Sources." Such nanotechnology storage mobile nanobattery work has an indirect support to herbal medicine research.

\section{Conflict of Interest Statement}

Both IFS and HIE state and declare that they have no any conflict in these current works.

\section{References}

[1]. Xing-Er Ye, Lin Bai, Yu-Shi Ye, Nian-He Xia, and Jana Leong-Škornicková, Taxonomic studies of Amomum (Zingiberaceae) in China II: transfer of Hornstedtia tibetica to Amomum and supplementary description of $\mathrm{H}$. hainanensis, Plant Systematics and Evolution 304, pp.1165-1180 (2018).

[2]. H.T. Luu, J. Leong-Škornicková, L.X.B. Nguyễn, C.T. Đỗ, and T.T. Hoàng, Newmania sessilanthera (Zingiberaceae): a new species from Vietnam, Gardens' Bulletin Singapore 67(2), pp. 351-355 ( 2015).

[3]. Hendry Izaac Elim (Elim Heaven), The Discovery of NEW Golobe and Its Amazing Healing System, Science Nature 2(1), pp. 66-70 (2019).

DOI: https://doi.org/10.30598/SNVol2Iss1pp066-070y2019

[4]. H.I. Elim, Scientific Breakthrough Based on Natural Creation: "1 Diamond with 7 Eyes", COJ Reviews and Research Vol. 1(1), pp.1-4 (2018)

[5]. H.I. Elim, Multitasking Herbal Nanomedicine: A Frontier Report,
[6]. H.I. Elim, Theory, Implementation and the Nature of Truth (TIN) in Nanoscience, Nanotechnology, and Nanomedicine (NNN): From the Beginning of Universe to nm Scale Behavior, Kenkyu Journal of Nanotechnology \& Nanoscience 5:33-36 (2019)

[7]. H.I. Elim, The First 1000 Atoms in Healing Process: From Nanotechnology to Nanomedicine, International Journal of Health Medicine and Current Research Vol. 3, Issue 04, pp.1044-1046, December, $2018 . \quad$ DOI: 10.22301/IJHMCR.2528-3189.1044

[8]. H.I. Elim (Elim Heaven), A.L. Mapanawang, and M.V. Reddy, A Creative Proposal to Improve Woman and Child Health: from the Knowledge of Physical Nanoscience to Nanotechnology Implementation and Products, CPQ Women and Child Health, 1(6), 01-11 (2019).

[9]. H.I. Elim, Nonlinear Optics and The Frontier of Nanoscience and Nanotechnology, Pattimura University Press, pp. 1-144 (2018). ISBN: 987-602-61906-9-7.

[10]. H.I. Elim, METODE FISIKA EKSPERIMEN: PELENGKAP TEORI FISIKA: “To be Perfect like The 1 Who Created Our Incredible Universe", Pattimura university press, Indonesia, pp. 1-155 (2018). ISBN : 978-602-5943-05-8.

[11]. H.I. Elim, Nanomedicine with Its Multitasking Applications: A View for Better Health, International Journal of Health Medicine and Current Research 2(02), 353-357 (2017).

[12]. H.I. Elim, Physics of Multitasking Nanomedicine, IJHMCR 2 (03), 509-519 (2017).

[13]. A. L.Mapanawang, F. Sambode, M. Killing, S. Mapanawang, B. Dijnimangake, A. Maengkom, P. Pranata, F. Mapanawang, H. Maengkom, H. Averous, A. Musa, W. Murary,

G. Mapanawang, Ismail, T. Sitanala, F. Syahputra, L. Lamidja, and J. Djafar, IDENTIFICATION OF ANTIOXIDANT ACTIVITY OF GOLOBE HALMAHERA (HORNSTEDTIA SP, INGIBERACEAE) FRUIT EXTRACT, International Journal of Pharmacy Review \& Research (www.ijprr.com), Vol. 6 (1), pp.31-34 (2016)

[14]. H.I. Elim, and A.L. Mapanawang, THE ATTRACTIVE DIFFERENCES OF TWO TYPES OF HERBAL MEDICINE FROM ZINGIBERACEAE FRUIT (GOLOBE HALMAHERA), IJHMCR 3 (01), 799-806 (2018).

[15]. A.L. Mapanawang, and H.I. Elim, Chemical Bonding Character of Love Herbal Medicine: A Prominent Medicine Candidate for 
The Observation of Fast, Long Term, and Stable Performance of Toxic Absorption in Herbal Blessing Product Based on Galoba Maluku (Zingiberaceae Fruits)

Preventing HIV virus, Nanotechnology \& Applications 1 (1),

1-4 (2018). DOI: 10.33425/2639-9466.1003 (ISSN: 2639-9466)

[16]. H.I. Elim, and A.L. Mapanawang, Electronics Physical System of Large Antioxidant Structure in Herbal Medicine based Zingiberaceae Fruit: Understanding and Application, Nanotechnology \& Applications 1 (1), (2018). DOI: 10.33425/2639-9466.1004 (ISSN: 2639-9466)

[17]. A.L. Mapanawang, and H.I. Elim, Unique Chemical Bonding Behavior of Love Herbal Medicine and Its Conjunction with Chemotherapy Drug, Journal of Nanomedicine and Nanotechnology 9 (3), 1000503 (2018) .
[18]. H.I. Elim, M.V. Reddy, and R. Jose, A Frontier 2D Nanobattery: "Improving Challenges (Hotumese) and Development", Science $\begin{array}{lllll}\text { Nature } & \text { 2(2), } & \text { pp. } & 114-121 & \text { (2019). }\end{array}$ https://doi.org/10.30598/SNVol2Iss2pp114-121y2019

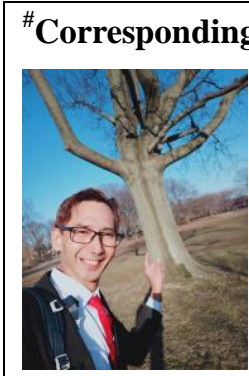

H.I. Elim, Ph.D is a young scientist (Assoc.Prof.) of Pattimura university from physics department in Faculty of Mathematics and Natural Sciences (FMIPA). Moreover, Dr. Elim has been working on the field of physics in nanoscience, nanotechnology and nanomedicine for about the last two decades. He built the first nanoscience research center and innovative creation (PPNRI) in the eastern part of Indonesia since April 2015 up to present. Such PPNRI has made worldwide impacts with many creative outputs both prototypes in superfibers with excellent mechanical and optical properties, and herbal medicine products. As a matter of facts, there were $\sim 75$ research undergraduate research students having their graduation certificates to face their adventure future in science and technology of working environment. Besides of the above mentioned achievements, Dr. Elim has published over 20 international publications in the institution of PPNRI, Pattimura university as well as presented vary invited talks in several prestigious international conference in the related fields such as in PharmaNano 2018, Last Vegas, and PharmaNano 2019, New York, USA. In addition, Dr. Elim has delivered a series of quest lectures on multitasking nanotechnology and nanomedicine in few important Indonesia universities, for instance: Univeritas Negeri Manado (UNIMA), Universitas sam Ratulangi (UNSTRAT), and Universitas Indonesia (UI). In summary, the best achievement that Dr. Elim has attained in his scientific contributions is the $\mathbf{H}$ index of $\sim 24$ based on SCOPUS/ Web of Science with citation over 2300 which distinguishes him as the $3^{\text {rd }}$ best Indonesia physicist in 2019

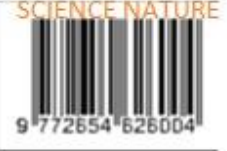

